Filol. Linguíst. Port., São Paulo, v. 15, n. spe, p. 27-67, dez. 2013

http://dx.doi.org/10.11606/issn.2176-9419.v15ispep27-67

\title{
Uma breve história da Etimologia
} A brief history of Etymology

\author{
Mário Eduardo Viaro * \\ Universidade de São Paulo, São Paulo, Brasil
}

\begin{abstract}
Resumo: Os estudos etimológicos nunca foram totalmente independentes da pesquisa linguística, embora tenham seu próprio método, o qual será apresentado de maneira historiográfica neste artigo. Passa-se do pensamento de Platão para a criação das leis fonéticas no Renascimento e seu desenvolvimento sob a ótica da Linguística Histórico-Comparativa em Gyarmathi, Rask e autores de língua alemã, bem como os novos pressupostos surgidos na primeira metade do século XX, quando houve uma interrupção, somente retomada no final do mesmo século. O conhecimento da História da Etimologia é particularmente importante para os futuros desenvolvimentos da informação etimológica da língua portuguesa.
\end{abstract}

Palavras-chave: Etimologia; História da Linguística; Epistemologia da Ciência.

\begin{abstract}
: the etymological studies never were independent of the linguistic ones, although they have their own method, which will be shown in this paper in a historiographical way. From Plato's thought to the creation of the Phonetic Laws during the Renaissance and to its development from the historical and comparative point of view of Gyarmathi, Rask and the authors from Germany, new assumptions are defined in the first half of the twentieth century, when there is a pause, resumed only at the end of the same century. The knowledge of the History of Etymology is
\end{abstract}

* Professor do Departamento de Letras Clássicas e Vernáculas da Faculdade de Filosofia, Letras e Ciências Humanas da Universidade de São Paulo - USP, São Paulo - SP; maeviaro@usp.br. Coordenador do Núcleo de apoio à pesquisa em Etimologia e História da Língua Portuguesa; nehilp@usp.br 
particularly important to the future development of etymological studies of the Portuguese Language.

Keywords: Etymology; Linguistics History; Epistemology of Science.

\section{PLATÃO E O SURGIMENTO DA ETIMOLOGIA NO OCIDENTE}

A consciência etimológica do ser humano é testemunhada, pelo menos, há vinte e cinco séculos. Nos textos sobreviventes de Heráclito de Éfeso (c540-470 a.C.), jogos de palavras apontam para uma Etimologia incipiente. Os seguidores de Heráclito viam o mundo como um movimento perpétuo. Como as semelhanças estariam escondidas, acreditavam que as palavras, após terem sido criadas, sofreram modificações que as tornaram como são hoje. Trata-se, ao que tudo indica, da primeira noção de diacronia no Ocidente.

Platão (c428-347 a.C.) explorará várias discussões de sua época em seus diálogos, nos quais essa visão de mundo transparece nos fatos. Etimologias aparecem de forma parcimoniosa em Protágoras 312c, 361d; Fedro 237a, 238c, 244b, 251c, 255c; Teeteto 194c; República 2:369c; Górgias 493a; Fédon 80-81d; Sofista 221c, 228d; Leis 2:654a, 7:816a, 12:957c, mas é no Crátilo, escrito por volta de 386-385 a.C. que esses problemas são discutidos de modo mais abrangente. Apesar de seu julgamento ambíguo a respeito das questões etimológicas, Platão foi o melhor intérprete de como a discussão se efetuava em sua época, embora não use nem o termo étymon nem a palavra etymología, que mais tarde se encontrarão em outros autores.

A certa altura do Crátilo, afirma que a essência do nome deve extrair-se das propriedades das letras e das sílabas (423e): o som $r$ denotaria movimento; $i$, a leveza; $p s, p h, s$, z, uma agitação etc. Essa adequação entre significante e significado será, ao final do diálogo, como visto, negada quando Sócrates mostra a Crátilo que deve haver algo de convencional nas palavras, senão "dureza" não seria chamada sklērótēs pelos atenienses e sklērótēr pelos falantes da Eritreia (434c-d). Essa indiferença na expressão parece negar o valor semântico supostamente natural, pois o $r$ e o $s$ não denotam a mesma coisa e, nesse caso, porém, parecem iguais.

Busca-se o étimo normalmente em palavras do próprio grego que se assemelham foneticamente ou em grupos de palavras, que se juntam numa composição hipotética. Nesse processo, diversos sons são acrescentados, subtraídos, transpostos ou transformados ao bel prazer. As letras do étimo e da palavra estudada normalmente têm alguma semelhança. $\mathrm{O}$ acento não tem qualquer papel 
e supostos deslocamentos nunca são explicados. Sócrates alega que a desfiguração da palavra original se devia a um "embelezamento". Nos casos mais problemáticos, aventa-se uma origem bárbara. São comuns os étimos-frases (ou seja, reduções arbitrárias de frases inteiras). Também nomes hipotéticos aparecem em muitos momentos do diálogo. Pautam-se, por vezes, em formas arcaicas. Por exemplo, o nome da lua (selēnē) é mais visível na palavra homérica selenaía, que remontaria a *selaenoneoáeia (409a-c), porque seu brilho (sélas) é sempre (aei) novo (néon) e antigo (bénon), seguindo o ensinamento de Anaxágoras (c500-428a.C.). Muitos étimos são obtidos por meio de adjetivos ou verbos que, de forma direta ou tortuosa, representariam a essência do objeto.

O que mais chama a atenção do leitor atual, são as múltiplas etimologias que não se excluem, pois muitas vezes mostrariam diversos ângulos do mesmo ser (406b). Assim, todos os atributos de Apolo se veem em seus múltiplos étimos: sua simplicidade (haploû), sua capacidade de acertar o alvo (aeì bállontos), seu dom purificador (apoloúōn) e seu poder para acompanhar os movimentos das coisas (homopoloúōn).

Platão imagina que as palavras dos povos bárbaros estarão mais próximas do momento original. Apesar de ser prática rara nos autores clássicos, chega a fazer alguma comparação interlinguística. Por exemplo, como Sócrates desconhece a etimologia da palavra "fogo" (pŷr), alude à sua semelhança com o vocábulo correspondente, usado pelos frígios (409d-e). Para Platão, também a língua grega primitiva devia ser algo incompreensível, pois provavelmente se assemelharia à dos bárbaros (414c). Tal afirmação revela notável reflexão intuitiva sobre a mudança diacrônica desenvolvida milênios depois.

Nesse diálogo, argumentou que formas antigas estariam próximas do momento da criação do nome, isto é, do seu étimo, por isso Homero é, muitas vezes, citado. Também os demais dialetos gregos, por não terem o suposto "refinamento ático", estariam mais próximos da origem. A deusa Hestía, por exemplo, se aproxima da palavra que significa "essência" (ousía), mas isso é particularmente visível somente em formas dóricas (essía ou ōsía). Com isso, Platão mostra que os atenienses preferiram a eufonia à verdade que emana do étimo (404d). Para ele, os dialetos não-áticos são mais conservadores e devem ser considerados, posição que o aproxima das conclusões da Dialetologia moderna. Platão também atribui à fala das mulheres um caráter mais conservador (418 b-c), argumento encontrado ulteriormente, por exemplo, em Cícero (De orat. 12) e Silva Neto $\left(1986^{5}: 55\right)$.

Por vezes, observa-se um caráter normativo nas sugestões etimológicas de Platão: para ele, o vinho (oînos) deveria chamar-se 丸 oiónous, pois dá uma ilusão de razão (nous) ao embriagado. Também gêe "terra" deveria ser chamada «gaîa, 
para satisfazer o étimo que apresenta. Segundo o mesmo raciocínio, diz ser preciso rejeitar o $e$-inicial de epistēmē "conhecimento" para que se chame $\star$ pistēmē, transparecendo, assim, a palavra pistós ("fiel") de onde deriva. Essa postura, contudo, é muito incipiente e sutil, uma vez que a ideia de uma gramática normativa sequer era imaginada nessa época.

\section{ISIDORO DE SEVILHA E O PENSAMENTO ETIMOLÓGICO NA ALTA IDADE MÉDIA}

Saltando 1200 anos, para o século VII d.C. na Alta Idade Média, na Espanha antes da entrada dos árabes na Península, encontramos a obra de Isidorus Sevillanus (c560-636), bispo de 600-636, que compôs as suas Etymologice, de caráter enciclopédico, durante o período dos visigodos. O número de étimos é imenso e os vinte livros dessa obra carregados de erudição (mais de 150 autores são citados) tratam de vários assuntos. Sobretudo no livro X (de vocabulis) é possível ver a aplicação da técnica etimológica em uma vasta lista de palavras, na maior parte, ordenada alfabeticamente. Uma das preocupações constantes de Isidoro é informar o que a palavra significa e, portanto, confundem-se, muitas vezes, significado e étimo.

Para Isidoro, Etimologia é a origem dos vocábulos, deduzida dos verbos ou dos nomes por sua interpretação (1:29:1-5). A etimologia - chamada sýmbolon por Aristóteles e adnotatio por Cícero - deixaria, segundo ele, as palavras evidentes e seu conhecimento (cognitio) seria necessário para a correta interpetação dos nomes (nam dum videns unde ortum est nomen, citum vis eius intellegis). Numa posição conciliatória entre a origem natural ou convencional da linguagem, crê que, nem todas as palavras teriam etimologia, pois algumas receberam os nomes não somente segundo a sua própria natureza (secundum qualitatem, qua genita sunt), mas também segundo a vontade humana (iuxta arbitrium bumanae voluntatis).

Como a maioria dos autores antigos, Isidoro, obviamente, seguia a intuição, sem um método evidente. Em vários casos, surpreende-nos com acertos, quando a semelhança nem sempre é tão óbvia, o que faz pensar que se tenha pautado em várias fontes clássicas. Isidoro tem consciência de que a origem dos nomes não é óbvia e, portanto, não é conhecida por todos, daí a razão de sua obra (10:1). A diretriz utilizada em suas etimologias, como em Platão, é a equivalência sonora parcial entre o suposto étimo e a palavra analisada.

Também a mudança vocálica comum nas formações por prefixação e em composições colaborava para reforçar a tese da anomalia. Não conseguindo ver claramente as regras que orientavam a apofonia, imagina haver uma relação aleatória entre as vogais do étimo e as da palavra explicada. É preciso, contudo, 
lembrar que a Etimologia, nesse período, se reduz, quase sempre, à sugestão de uma aproximação. Desse modo, alacer "rápido" é explicado "como se fosse dotado de asas", quasi aliger (10:6). A apresentação de palavras hipotéticas intermediárias também é feita mediante a fórmula quasi "como se". Por exemplo, para explicar a palavra littera "letra", diz que é quasi legitera (1:15:1), termo hipotético explicado ou como aquilo que mostra o caminho para os leitores (legentibus iter) ou como aquilo que se repete lendo (in legendo iteretur). Formas hipotéticas e alternâncias vocálicas estão sempre juntas nos étimos isidorianos: de origem grega seria o composto *leopus "pé de leão", de onde teria vindo a palavra lupus "lobo", étimo proposto devido à força atribuída aos pés do lobo (12:2:23-24). O nome apes "abelhas" se derivaria, segundo Isidoro, de um homófono *apes, étimo híbrido que indica que esse animal não ( $\mathrm{gr} a$-) têm patas (lat pes) ao nascer (12:8:1). O topônimo Etruria viria de *heteroúria, formado do gr béteron "outro" e do gr óros "montanha" (14:4:22) e a ilha de Naxos, de *Dionaxos, palavra inspirada no deus Dionísio (14:6:27). O princípio mais evidente, como se pode observar, é a proximidade sonora e algum percurso semântico é apresentado, em geral, de forma mais sucinta do que em Platão.

Os metaplasmos (1:25) já eram conhecidos pelos romanos (latine transformatio). As regras de adição, subtração, transposição e transformação eram aplicadas de forma quase aleatória, seja com dados da língua antiga, seja por meio da imaginação: crudelis "cruel" viria de rudus "rude", com o acréscimo do $c$-; clamosus "barulhento" viria de *calamosus (associado a calamus "vara", isto é, "que soa"), com a subtração do primeiro - $a$ - (10:41).

De um modo geral, a Etimologia isidoriana parece mais caótica que a platônica, pois, muitas vezes, a semelhança entre o étimo e a palavra investigada é de apenas uma ou duas letras, como é o caso de amulus "imitador" que proviria de imitari "imitar" (10:7) ou vagus "errante", de sine via "sem caminho" (10:280).

A explicação etimológica de Isidoro confirma, inevitavelmente, algum saber da época, o que lhe dá um certo sabor antiquado. Movido pelo consenso cristão, ousa corrigir algumas autoridades, dando preferências a outros étimos. Desse modo, não concorda que homo provenha de humanitas (1:19:3, 10:1, 11:1:4), como queriam alguns filósofos, pois prefere o testemunho bíblico, quando diz que o homem veio da terra (bumus), no livro de Gênesis 2:7 (Et creavit Deus hominem de bumo terre). Também a palavra annus "ano" remontaria a um *annuus, alteração de anulus "anel", pois o ano volta a si mesmo como um círculo (5:36:1). 


\section{NEBRIJA E NUNES DE LEÃO: A ETIMOLOGIA NO RENASCIMENTO NA PENÍNSULA IBÉRICA}

Novo salto de um milênio no percurso historiográfico lança-nos a um livro sobre Etimologia que tem grande valor para a língua portuguesa. Em 1492, Elio Antonio de Nebrija (1444-1522), pseudônimo de Antonio Martínez de Cala y Xarava, entendia que o castelhano era, na verdade, latim modificado. O termo "corrupção" usado no Renascimento para a mudança linguística deve, portanto, ser entendido, não como deterioração, mas como transformação promovida por um denominador comum, a saber, o parentesco (cercanidad) entre as letras (Introductiones latine, 1488, fol. 36r). Apoiado nesse modelo de que o castelhano é latim modificado, Nebrija apresenta algumas regras (12r), que antecedem as "leis fonéticas" do séc XIX. O grau de acerto é assombrosamente grande.

No prosseguimento das gramáticas italianas e francesas, as gramáticas ibéricas do século XVI logo se voltaram à questão da Ortografia. Duarte Nunes de Leão (c1530-1608) publicara uma Ortografia da língua portuguesa (1576), no qual se antevê um estudo etimológico em várias passagens, sobretudo no terceiro capítulo, fortemente inspirado nas "corrupções" de Nebrija. Refletindo sobre a transformação promovida nas palavras, pela passagem do tempo, Nunes de Leão publicará, mais tarde, outro livro, totalmente dedicado à questão, Origem da língua portuguesa (1606).

Qualquer leitor familiarizado com as ideias divulgadas pela Historiografia (que costuma colocar o mais recuado início dos estudos científicos da Linguística no século XIX) não deixará de se surpreender com as corrupciones de Nebrija e com o tratado de Nunes de Leão, que, do ponto de vista da história dos povos e da história interna do português, não deixam nada a dever às obras novecentistas. No prefácio da quarta edição da obra (1945), José Pedro Machado calcula que dos 147 vocábulos analisados por Nunes de Leão no capítulo VIII, apenas 40 não estão corretos. Outros autores, anteriores a Nunes de Leão, também fizeram etimologia com notável número de acertos, como o italiano Pier Francesco Giambullari (1495-1555) em seu Il Gello (1549).

Se, para Isidoro, os metaplasmos são necessidades estilísticas (propter metri necessitatem et licentiam poetarum 1:35:1), para Nebrija, suas quatorze espécies refletem a própria mudança linguística (Ilama se en griego metaplasmo que en nuestra lengua quiere dę̧ir transformacion 48v). Há uma flagrante transposição da língua escrita para a falada. O chamado "parentesco das letras" está na base das transformações fonéticas percebidas pelos autores, o que transformou a tarefa etimológica em algo mais pormenorizado. Ao mesmo tempo, com o Renascimento, retomam-se os textos platônicos (Nunes de Leão, aliás, cita o Crátilo, em Orig 5) e, 
com eles, a herança da ideia heraclitiana do mundo em movimento (discurso do tempo), aplicada às palavras, volta a sentir-se. Isso equivale a dizer que há, nesse período, com o aparecimento das gramáticas das línguas vernáculas, não só há a consciência da diacronia das palavras (como em Platão), mas também da transformação dos sistemas (do latim ao castelhano ou ao português). A influência de Nebrija sobre Nunes de Leão é indiscutível (alguns equívocos comuns o comprovam), mas isso não diminui a obra do autor português, como já se fez Nunes de Leão aplica e amplia o método de Nebrija, transcendendo seus objetivos, pois já utiliza um método comparativo. Valendo-se do toscano, do castelhano e do português, compara os encontros $c l$, $f l$, pl em tabelas que pretendiam mostrar a "proporção" de correspondência entre as línguas. Esses quadros lembram os feitos por Rask no século XIX (Ort 4). Nunes de Leão conclui que "pela analogia e correspondencia de ũas linguas a outras" é possível conhecer a origem de outros vocábulos "que por outra maneira não poderiam alcançar":

Nunes de Leão em sua Origem apresenta-se mais teórico do que na Ortografia. Sua tese diacrônica fundamenta a visão da língua em constante mutação: "Assi como em todas cousas humanas ha continua mudança, छo alteraçã̃, assi he tambem nas lingoagẽs (...) polo que em hũa mesma lingoa vã̃ fazendo-se tantas mudanças de vocabulos, que per discurso do tempo, fica parecendo outra" (Orig 1). As inovações são ou voluntárias, ou necessárias, como no caso do grego, que teria fornecido ao português termos para a denominação de doenças, partes do corpo, ervas e plantas, pedras preciosas, assim como para áreas do conhecimento, como Arquitetura, Ginástica, Música, Poesia, Geometria, Astronomia, Astrologia, Gramática e Religião (Orig 5). Essa transformação das línguas ocorreria abandonando algumas palavras, substituindo-as ou modificando-as. Nunes de Leão tinha consciência de que as línguas se modificavam consideravelmente na passagem do tempo: pelo discurso do tempo se vã̃ desemelhando hũas lingoas de outras com que tinhaõ algũa semelhança, Ẽ consigo mesmas, tanto que ficaõ parecendo outras (Orig 5).

Os tipos de corrupção enumerados por Nunes de Leão são mais amplos que os de Nebrija, pois não se circunscrevem apenas à corrupção das letras. Fala da mudança das terminações das palavras (lat sermo > sermão, lat prudens $>$ prudente), de modificações por diminuição de letras ou sílabas (lat mare $>$ mar, lat nodo $>$ noo, lat sagitta $>$ seetta), de acréscimo de letras ou sílabas no início, meio e fim da palavra (lat umbra $>$ sombra, lat stella $>$ strella, lat cor $\rightarrow$ coração), de troca e transformação de letras (lat ecclesia $>$ igreja, lat desiderĭum $>$ desejo, lat * cupiditĩam $>$ cobiça e muitas já citadas), de troca de letras por outras não semelhantes (lat mimus $>$ momo, lat pustula $>$ bostela, lat cumulare $>$ cogular) e de deslocamento de letras de um lugar para outro (lat fenestra $>$ feestra, lat feria $>$ feira, lat vicario $>$ vigairo, lat niger $>$ negro, lat pauper $>$ pobre). 
Nesse sentido, sente-se que Nunes de Leão aplica os metaplasmos e outras figuras retóricas nas regras de corrupção, sem dizê-lo explicitamente. Por isso, a transformação pode ocorrer também em outras situações, pois pode haver corrupção por mudança de gênero (cor, flor, goma, nariz, lacryma), por mudança de número (arma, escada, grades, grelhas), por mudança de significado (lat macula $>$ malha $\approx$ mágoa $\approx$ mancha, lat pulvere $>$ pó $\approx$ polvora), por impropriedade do uso de significado (lat fur $\sim$ latro $>$ ladrão, lat vocare $\sim$ clamare $>$ chamar etc.), por metáfora (abelhudo, taludo, viver a olho) etc.

A surpreendente atualidade dessas observações deixa claro que muitos autores dos séculos XIX e XX se serviram do raciocíno e até dos exemplos de Nunes de Leão, sem citá-lo. Nos capítulos subsequentes (Orig 8-15), faz longas listas, em parte confusas, mas com grande número de acertos, para palavras provenientes do latim, grego, árabe, francês, italiano, alemão, hebraico, sírio e godo.

\section{LEIBNIZ E A PRIMEIRA VERSÃO DA TEORIA INDO-EUROPEIA}

Nunes de Leão está separado por um século de Gottfried Wilhelm von Leibniz (1646-1716), o qual, numa de suas mais importantes obras, Nouveaux essais sur l'entendement humain (escrita entre 1701-1704, mas publicada postumamente, apenas em 1765), aponta os supostos erros do famoso Essay concerning human understanding (1609), de John Locke (1632-1704), na forma de um diálogo no estilo platônico entre Teófilo (que representa a própria postura de Leibniz) e Filaleto (cujas falas correspondem a Locke e seus seguidores). O terceiro livro dessa obra, sobretudo nos dois primeiros capítulos, é dedicado às palavras (Des mots). Nele faz um panorama da preocupação etimológica no início do século XVIII. Na verdade, tais comentários derivam-se de vários estudos sobre questóes de Filologia e Etimologia, alguns publicados também postumamente, por Dutens (1768, vol 6, parte 2).

Segundo Leibniz, existe, nas palavras, um primeiro significado (primiére signification). Por exemplo, o vocábulo espírito designa o "sopro" (lat spiritus), anjo seria um "mensageiro" (gr ággelos). Esses significados ocultos são suas etimologias. A análise das palavras em si poderia ensinar-nos conexões que a análise dos seus significados evidentes (notions) não pode fornecer por meio da razão. Esse método seria aplicável inclusive para as preposiçóes, pois nelas sempre existem primordialmente significados como lugar, distância e movimento. A partir deles nasceriam outras noçóes. Nesse item específico, antevê toda a discussão sobre gramaticalizaçáo, que aparece na Linguística dos séculos XX e XXI (Viaro, 1994; Heine \& Kuteva, 2002). 
Leibniz, porém, acredita que a maioria dos étimos (les vrayes etimologies) se perdeu, pois o decorrer do tempo e as mudanças semânticas os obscureceram. Ao contrário de Locke, crê que as palavras são determinadas por motivos naturais e somente as línguas artificiais são arbitrárias. Também seriam arbitrárias as gírias, como o rothwelsch, a lingua zerga e o narguois. As demais línguas naturais se derivaram de outras, mais antigas. $\mathrm{O}$ significado das línguas altera-se, por meio de metáforas. Novos vocábulos se cunham por composição e derivação. As línguas surgiram, assim, do relacionamento entre os povos: quando vizinhas, misturaram-se, sendo que uma delas foi tomada por base. Essa alteração ou corrupção se dera pelo acréscimo de palavras, como ocorre com línguas próprias para o comércio entre diversos povos. Conclui que todas as línguas de sua época estariam profundamente alteradas e isso é observável quando as comparamos com formas mais antigas. Entre os exemplos, observa que o francês antigo se parecia mais com o provençal e com o italiano do que com a língua moderna. Também cita o alemão do Evangelho de Otfried von Weissenburg e, por fim, o Codex Argenteus, do século IV, escrito em gótico, por Úlfilas, o qual, embora muito distinto do alemão moderno, tinha a mesma base linguística (le meme fonds de langue).

Antes de Leibniz, vários autores haviam observado a semelhança entre as línguas. Sobretudo o parentesco das línguas semíticas já era conhecida desde a Idade Média. A semelhança entre as línguas semíticas era, portanto, na época de Leibniz, um fato demonstrado por muitos autores. Leibniz cita que as semelhanças entre o húngaro e o finlandês eram conhecidas desde Johannes Amos Comenius (1592-1670), assim como entre o finlandês e o lapão, por Johannes Schefferus (1621-1679). Antes ainda, no século XIII, Willielmus de Rubruquis já havia percebido semelhanças entre o húngaro e as línguas turcas. Também na época de Leibniz, a antiguidade do gaulês era bastante discutida por Joachim Périon (1499?-1559), Philippe Cluwer (1616) e Paul Yves Pezron (1703), o que motivou a comparação das línguas célticas feita por Edward Lhwyd (1707).

Quando Leibniz compara o antigo texto gótico de Úlfilas com o alemão, na verdade, pretende demonstrar que o elemento germânico e o gaulês procederam de uma fonte única, ainda mais antiga, a qual imagina ser o céltico. Num texto de 1710, Brevis designatio meditationum de originibus gentium, reimpresso no vol. 4 de Dutens (1768, pp. 186-198), Leibniz dá mais detalhes de sua teoria. Palavras de uma língua antiquíssima (vetustissima lingua) difundida em uma regiáo muito vasta (ab Oceano Britannico ad usque Japanicum) se encontrariam nas mais diversas línguas. Leibniz não duvida que se encontrem resquícios dessa língua primitiva na África e na América. As línguas modernas, portanto, proviriam da mistura e corrupção de outras mais antigas, de modo que nenhuma poderia dizer-se pura. Vestígios da língua antiquíssima se veriam, segundo ele, 
nos topônimos. Não lhe dá nenhum nome específico, embora cite, nos Nouveaux essais, o termo adâmico, cunhado por Jacob Böhme (1575-1624). Como outros autores de sua época, Leibniz não acredita que o hebraico seja a língua original.

No entanto, acredita que num passado remoto havia dois grandes grupos: as meridionais poderiam chamar-se de arameias, ao passo que as setentrionais seriam as japéticas (que equivale, em toda sua explicação, ao que atualmente chamaríamos de indo-europeu). Leibniz retoma a questão da origem natural das línguas. Como dito, na sua postura, contrária à de Locke, os idiomas não são instituiçóes arbitrárias (ex instituto), mas elementos naturais, que, mais tarde, foram ajustados (naturali quodam impetu nate hominum sonos ad affectus motusque animi attemperantium). Para demostrá-la, argumenta que é possível estabelecer uma relação entre as palavras e seus sons. O simbolismo das letras, já visto em Platão, é, retomado de forma vigorosa contra a tese da arbitrariedade entre som e significado. Segundo Leibniz, determinar tais elementos nem sempre é possível, por causa dos percalços e mudanças, de modo que a maioria das palavras está extremamente alterada e distanciada da sua pronúncia e significado originais.

Outro pressuposto de Leibniz é o de que as primeiras palavras se formaram de onomatopeias (tales detegunt sese prime origines vocabulorum, quoties penetrari potest ad radicem tês onomatopoíias) e os vocábulos proviriam da analogia (ex analogia). Para comprovar essas teses, seria preciso estudar línguas de vários povos e criar critérios claros para propor etimologias. Não se deveria, por exemplo, dar fé às etimologias tradicionais, a não ser quando houvesse boa quantidade de indícios que as sustentassem. As etimologias feitas sem a pesquisas desses indícios são referidas por Leibniz pelo neologismo goropiser "goropizar". Esse termo faz alusão a Johannes Goropius Becanus (1518-1572), cuja obra Hermathena (1580) se tornou bastante conhecida, por sua fantasiosa tese de que o holandês teria sido a língua do Paraíso. Esse autor não estará sozinho na identificação da língua-mãe com uma língua viva: John Webb (1669) achava que era o chinês, já Andreas Kempe (1688) defendia ser o sueco. O exagero de Becanus tornou-se proverbial e recebeu duras críticas emitidas por Justus Lipsius (1547-1606), Joseph J. Scaliger (1540-1609) e Hugo Grotius (1585-1645). Leibniz também refuta o modelo estático de Becanus, uma vez que, para ele, as línguas estão em constante movimento e nenhuma preservaria, portanto, a sua pureza original. Embora o chauvinismo de Becanus tivesse admiradores, como Abraham Ortelius (1527-1598) ou Richard Hakluyt (c1552-1616) e até alguns seguidores, como Cornelis Kiliaan (c1529-1607), suas soluçóes escancararam, de certo modo, a necessidade de haver algum método que devesse ser empregado na identificação das etimologias. No entanto, desconhecidas as preocupaçôes e soluçóes esboçadas em Nebrija e Nunes de Leão, os próprios étimos de Leibniz (presentes em diversos textos) não 
ultrapassaram a livre associação, também presente nos autores da Antiguidade, pois se limitavam às semelhanças fônicas entre o étimo e a palavra investigada.

\section{GÉBELIN: O ROMANTISMO E A QUESTÃO ETIMOLÓGICA}

No final do século XVIII, os étimos eram vistos como algo natural (phýsei), como em Leibniz, que rechaçava a arbitrariedade (thései) na denominação das palavras primitivas. Tal postura se tornou ainda mais evidente no discurso de outros autores. Tanto para a filosofia de Jean-Jacques Rousseau (1712-1778) quanto para ideia dos gritos instintivos e dos gestos como precursores da linguagem em Étienne Bonnot de Condillac (1715-1780) e Charles de Brosses (1709-1777), esse componente exerceu um papel bastante importante. Mais especificamente na área da Linguística, ideias decorrentes dessa discussáo se tornaram notórias, por meio de Johann Gottfried von Herder (1744-1803). Para Herder, a linguagem não é obra de Deus, pois não é lógica, nem racional, pelo contrário, é caótica e mal-arranjada. Tampouco é uma invenção do homem. Surgira da necessidade, como os gritos dos animais e emergira de algum impulso natural, como o do embriāo que pressiona para nascer. A linguagem humana, contudo, distinguir-se-ia da comunicação animal, não apenas em grau, mas também em novos poderes. Toda uma linha da origem das línguas, associada às onomatopeias, surgirá de suas ideias, as quais aparecem em vários momentos de sua obra, sobretudo no seu premiado ensaio de 1772 (Abhandlung über den Ursprung der Sprache). Entre as características da língua primitiva, provinda do Oriente, estaria a abundância de sinônimos e de metáforas.

No ano seguinte, inicia-se a obra Monde Primitif, de Antoine Court de Gébelin (c1719-1784), cujos nove volumes, publicados até 1782, trazem muitas etimologias, as quais, por um lado, revitalizam algumas ideias antigas e, por outro, associam as línguas europeias às do Novo Mundo. Gébelin defende no vol. IX (Discours préliminaire sur les origines grecques) que haja uma ciência etimológica (science étymologique), a partir da prática iniciada por Platão, de comparar o grego com o frígio. Gébelin lamenta que Platáo ou que outro jovem sábio posterior (quelque jeune Lettré) não tenham seguido esse método ou explorado essas relaçóes, mas acredita que isso só seria possível na época em que vivia. Entre suas conclusóes, Gébelin demonstra que o grego não deve sua existência nem ao hebraico, nem ao alemáo, nem ao sueco, nem ao gótico, nem ao fenício, nem ao persa, nem ao indiano, mas à primeira língua da Europa, o céltico, que, por sua vez, seria irmã de uma língua oriental. Veem-se várias das teses de Leibniz aceitas agora de forma dogmática. A obra de Gébelin mostra uma espécie de síntese da Etimologia dedutiva (Platão, Isidoro de Sevilha, Leibniz) com a indutiva (Nebrija, Nunes de Leão), 
feita num contexto de maduro conhecimento das línguas do mundo, mesclados a uma visão pré-romântica da procura de uma sociedade primitiva.

Outra obra de Gébelin (1776), extraída da anterior, discute todas essas questóes associadas ao que chama de Gramática Universal (grammaire universelle). Tratando da história natural da fala, subdivide o texto em três partes: Etimologia, Escrita e Gramática. A Etimologia ensinaria a razão das palavras (raison des mots). Gébelin acredita que todas as línguas são apenas dialetos de uma só e as diferenças que reinam entre os idiomas não podem impedir que se reconheça que todos tenham a mesma origem, que julga ser uma língua monossilábica. Acredita que a comparação do maior número de línguas possível nos poderá conduzir à expressáo primitiva e ao verdadeiro étimo de cada palavra. Intui que quanto mais familiar for o uso de uma palavra, maior será sua alteração. Em vez de chegar ao indo-europeu, porém, Gébelin, com seu método à procura da língua primitiva, acabou por extrapolar: do fr parole e fr parler, por exemplo, retira uma suposta raiz * PAR, com correspondências em bretáo, hebraico, alemáo, irlandês e latim. As regras para o estabelecimento das raízes originais, ou seja, do étimo mais remoto, são explicitamente declaradas, embora sua aplicação seja pouco clara.

\section{O SURGIMENTO DO MÉTODO ETIMOLÓGICO NO FINAL DO SÉCULO XVIII}

\subsection{Gyarmathi}

As opiniōes de Leibniz tiveram grande impacto na Filosofia e nas ciências. Sob sua influência, Pedro, o Grande (1672-1725), czar da Rússia, mandou coletar vocábulos de várias línguas de seu império. Esse impulso, continuado por Catarina II (1729-1796), gerou obras como a de Peter Simon Pallas (1741-1811) e, indiretamente, de Sámuel Gyarmathi (1751-1830), o qual dista muito de Gébelin pelo tratamento empírico dos dados coletados e pela sua análise austera. Como outros autores antigos já haviam aventado (inclusive Leibniz), Gyarmathi demonstra, baseando-se num grande número de exemplos, que o húngaro - uma língua europeia - possuía de fato parentesco com outras, consideradas "primitivas", faladas em lugares muito distantes, no Oriente. O elemento inovador dessa comparação e o grande mérito de Gyarmathi, porém, foi o de privilegiar os elementos gramaticais, em vez de - como usualmente se fazia - atentar somente às semelhanças lexicais. Gyarmathi ordenará, em seu livro, longas listas em que demonstra o parentesco não só entre o húngaro e o lapão, mas também inclui o finlandês e o estoniano (a inclusão dessa última língua no mesmo grupo já tinha sido suposto por Leibniz). Vai mais além, provando também a semelhança com 
muitas outras línguas urálicas (cheremisse, mordvino, votiaco, tchuvache, zirieno, vogul, pérmico) e aparentadas (samoiedo, ostiaco). Também leva em consideração o elemento tártaro, o turco e parte do vocabulário de línguas eslavas (russo, sérvio, boêmio, polonês).

Além das semelhanças das palavras, um novo tipo de investigação se inaugurará na busca da origem das línguas: a das semelhanças gramaticais. Cada vez mais os pronomes, numerais e terminaçóes serão confrontados e se tornarão decisivos para a determinação de uma origem comum. O próximo século trará um salto de qualidade na perspectiva diacrônica e confirmará o insight de Gyarmathi, a tal ponto que a Historiografia costuma distingui-lo como o início de uma visão "científica" da Linguística, o que é particularmente injusto para a figura de seus precursores. Desse modo, os avanços dos séculos anteriores e as hipóteses arriscadas, como a de Gébelin, serão abandonadas ou aproveitadas sem menção a seus autores. Por fim, suas obras tornaram-se esquecidas ou ignoradas, sem que uma revisão crítica e imparcial tivesse sido feita. Somente hoje releem-se os autores do século XVIII, o que confirma sua importância para o estudo da Linguística.

O século XIX vivenciará, nas suas três primeiras décadas, um tremendo progresso na quantidade de dados e na qualidade da pesquisa linguística e, por conseguinte, do método etimológico. Em 1806 saía o primeiro volume da grande obra de Johann Christoph Adelung (1732-1802), que será de grande importância para o desenvolvimento da Linguística Comparativa. Todo o terreno já estava pronto para as duas obras que iniciam, como informam os manuais de Historiografia, a chamada "fase científica" da Linguística.

\subsection{O pionerismo de Rasmus Rask}

O título de "pai da Linguística Comparativa" normalmente se divide entre o dinamarquês Rasmus Christian Rask (1787-1832) e alemão Franz Bopp. Apesar de o livro do Rask ter saído dois anos depois da obra de Bopp, ou seja, em 1818, o manuscrito é de 1814, quando estava na Islândia e tinha 27 anos. A obra de Rask difere bastante da de Gyarmathi e da de Bopp. A partir do antigo islandês estabelece princípios de reconstrução muito antes de Schleicher. Sua preferência pelo islandês, a mais conservadora das línguas nórdicas, se evidencia na profusão de obras que publica sobre o assunto. Rask - como fez Gyarmathi - enfocou o sistema gramatical e não o léxico. Sua tese é a de que as línguas mais complexas do ponto de vista gramatical se aproximam da língua-máe da maioria das línguas europeias (chamada de "trácio") e que, para provar o parentesco linguístico, o estudo dos pronomes e numerais é decisivo. Ao fazer a comparação, percebe-se que as coincidências estruturais são grandes demais para ser obra do acaso. 
Na sua obra de 1818, Rask afirma que os gregos e os romanos não trataram seriamente a Etimologia (en Disiplin, som Graker og Rommere ikke egentlig dyrkede) e considera insuficientes e não muito científicas (ufyldestgjörende og uvidenskabelig) as informaçóes de contemporâneos, como Johann Nicolaus Tetens (1736-1807), Carl Ferdinand Degen (1766-1825), Johan Ihre (1707-1780) e de antigos como Gerardus Joannes Vossius (1577-1649). Não sabemos se Rask leu Nebrija ou algum seguidor, mas o seu método comparativo se assemelha à intuição do autor espanhol. Dista dele, porém, pela comparação multilíngue (que aparece, no entanto, em Nunes de Leão, em Gébelin e em Gyarmathi). Percebe, porém, a falta de registros de uma língua anterior ao islandês, semelhante ao latim para as línguas românicas. Essa língua antiga (de gamle Stammesprog) é o objetivo de suas investigaçóes etimológicas (etymologisk Undersögelse), de onde proviriam suas considerações teóricas acerca dos étimos (teoretiske Etymologi). Segundo Rask, as línguas germânicas proviriam do "gótico", termo equivalente ao que hoje chamaríamos de germânico, uma vez que o gótico propriamente dito é chamado de "mesogótico" (mesogötisk). A Etimologia deveria ser obtida empiricamente, por meio de dados. Dessa forma, a palavra dinamarquesa Söndag "domingo" não proviria (como dizia Peder Syv) de *Sohndag, ou seja, o "dia da reconciliação", pois se assemelha ao islandês sunnudag ou ao alemão Sonntag, literalmente "dia do sol". O antigo método (de Platão e Isidoro de Sevilha) estava definitivamente desacreditado. Nascerá a necessidade de provar a relação etimológica mediante regularidades e correspondências, como em Nebrija e Nunes de Leão. Rask propóe-se a detectar as etimologias forçadas ou falsas (tvungen og falsk) e, para tal, inaugura o princípio moderno da ciência etimológica, atribuído normalmente aos neogramáticos do final do século XIX.

Como distingue as palavras lexicais (leksikalsk) das gramaticais (grammatikalsk), confere, na sua rigorosa metodologia, maior importância aos primeiros do que aos segundos (como Hervás y Panduro e Gyarmathi), em questóes que transcendem o problema inicial da origem do islandês.

Para ele, terminaçóes e flexóes desaparecem, com o passar do tempo e é mais comum haver empréstimos de palavras do que de terminaçóes. Uma língua, mesmo misturada, porém, pertenceria à mesma classe de outras menos misturadas e o conjunto teria em comum algumas palavras tidas como primárias: "céu", "terra”, “mar”, “cabeça”, “olho”, “mão”, “pé”, “cavalo”, “vaca”, “bom”, “grande”, "pequeno”, "amar”, “ir” etc, sem falar das preposiçôes, pronomes e numerais.

Rask hesita com relação à afiliação do celta com o grupo pesquisado, mas concorda que haja parentesco com o eslavo, o lituano e o letão e apresenta semelhanças detalhadas entre o grego e o latim. Surpreende ainda hoje a coleta feita por Rask, a precisão de seus argumentos e as correspondências que encontra antes 
de Grimm. Rask alerta que é possível encontrar semelhanças em quaisquer grupos de línguas. É preciso, portanto, para não se fazerem agrupamentos errôneos, detalhar quais seriam as equivalências sonoras (Overensstemmelser immellem tvende Sprog) e retirar regras delas (Regler for Bogstavernes Overgange).

Muito antes de Diez, até mesmo o português entra nessas comparaçóes (por exemplo, lat focus $\cong$ port $f \circ g o \cong f r f e u$ ). Encontra correspondências entre o mesogótico, o islandês, o grego e o latim, as quais não se circunscrevem apenas à apresentação de tabelas de vogais e consoantes (antecedendo Grimm), mas também apontam para semelhanças estruturais, como em Gyarmathi. Apresentam-se equivalências de casos, pronomes, numerais e conjugaçóes verbais. Rask, como Nunes de Leão, também não é indiferente à mudança semântica e apresenta diversos exemplos, nas suas comparações (rus gost ${ }^{\prime} \cong$ pol góśćc $\cong$ alem Gast $\cong$ isl gèstr "hóspede" ミ lat hostis "estrangeiro"). Também fala de mudança gramatical e sugere que as palavras nas línguas românicas não provêm do caso nominativo, mas do ablativo (hoje considera-se o acusativo como o caso lexicogênico).

Por fim, faz uma longa lista de 352 correspondências entre substantivos, adjetivos, verbos, pronomes, advérbios e preposiçóes. Rask é muito detalhista em questóes de Fonética. Os sons participam de vários fenômenos como a "mudança" (ombyttelse), visível em pares dentro da mesma língua (lat pendo "pesar" - lat pondus "peso", lat sedeo "estar sentado" - lat sido "sentar-se") ou entre línguas distintas. Quase todas as correspondências interlinguísticas apresentadas são corretas, segundo os moldes atuais. Muitas são pouco evidentes. Além das transformaçóes, Rask menciona as metáteses (omsatning) de $r, s, l$ :, quedas de sons (forögelse) e acréscimos (indskydelse), sobretudo epênteses.

Rask não se vale do sânscrito, do céltico ou do albanês, embora documentos e obras póstumas (1834) mostrem que, desde 1818, propunha uma reunião que se assemelha muito ao que mais tarde se chamará de "indo-europeu". Essa reunião incluiria o indiano (decânico e hindustânico), o iraniano (persa, armênio e osseta), o trácio (grego e latim), o sármata (letão e eslavo), o gótico (germânico e escandinavo) e o céltico (bretão e gaélico). Mais tarde incluirá ainda o albanês e o armênio (1832).

Muitos historiógrafos modernos ainda compartilham a ideia, vigente na segunda metade do século XIX, de que a Gramática Histórico-Comparativa teria sido fundada por Bopp, mas Rask foi, sem dúvida, o que melhor comprovou a existência do indo-europeu (que chama de "trácio"). Bopp inicialmente só se interessou pelo germânico, sânscrito, latim e grego. As línguas que aparecem já na obra de Rask em 1818 (por exemplo, o lituano e o eslavo) só serão aceitas por Bopp quase vinte anos depois. O fato de Rask não falar do sânscrito, porém, foi decisivo para o esquecimento paulatino de sua obra em uma época em que se 
idealizava a Índia, como veremos abaixo. Rask, embora reconhecido no início do século XIX, acabou sendo esquecido algumas décadas depois, pelos divulgadores e historiógrafos da Linguística, que valorizaram apenas os subsequentes autores de língua alemã.

\subsection{A contribuiçáo dos alemães no século XIX}

\subsubsection{Bopp}

Um ano antes de Gyarmathi publicar seu trabalho, o padre Paulin de Saint-Barthélemy escrevera uma dissertação que aproximava o zende, o sânscrito e o alemão (1798). A ligação entre as línguas da Europa e da Ásia, na verdade, se antevia desde antes de Leibniz. O célebre discurso de Sir William Jones (1746-1794) na Asiatic Society, no entanto, é considerado um marco para os estudos linguísticos, mas semelhanças entre o sânscrito e outras línguas europeias já haviam sido observadas por Filippo Sassetti em 1585 e por P. Cœrdoux, em 1767 (impresso em 1807). Em 1808, Karl Wilhelm Friedrich von Schlegel (1772-1829) já falará de gramática comparativa, chegando a fazer associaçóes que serão ulteriormente desenvolvidas por outros autores (lat $f \cong \operatorname{esp} h$, lat $p \cong \operatorname{alem} f$ etc.).

No entusiasmo do início do século XIX, apesar da maturidade das reflexóes de Gyarmathi e Rask, é, sobretudo, a Franz Bopp (1791-1867) que os manuais de Historiografia atribuem o início da Linguística científica. O suposto marco seria sua ainda tímida obra de Bopp, de 1816, escrita aos 25 anos. Quatro anos depois, o comparativismo se tornará mais explícito em seu método. Uma década depois, seu nome se consagrará completamente, por ocasião da publicação de sua grande obra, a Vergleichende Grammatik, muito mais extensa (18331852). São inegáveis as influências que teve de Grimm e de Rask depois de 1816.

Autointitulando-se um "pesquisador da língua" (Sprachforscher), Bopp impóe-se um método dedutivo, bastante diferente do de Rask, no qual o sânscrito tem papel central. Por ser uma obra em que os aspectos literários e filosóficos assumem um primeiro plano, observa-se claramente que as influências de Bopp são diferentes das de Rask. Entre elas, citem-se o barão Antoine-Isaac Silvestre de Sacy (1758-1838) e a obra De emendanda ratione Graeca grammatica (1801), de Hermann Gottfried (1772-1848), a qual enfatiza a teoria da existência de uma cópula hipotética que atuaria sempre como ligação entre o sujeito e o predicado. Da obra Epea pteroenta (1806-1807), de John Horne Tooke (1736-1812), Bopp retira a ideia de que as desinências são, na maior parte das vezes, reduçóes do verbo "ser". Só as subsequentes obras de Bopp adotarão o mesmo método comparativo de Rask. 
O título de fundador dos estudos histórico-comparativos a Bopp aparece, porém, desde que Joseph-Daniel Guigniaut (1794-1876) comenta sua obra em 1869. Comparando com Rask, a "obra fundadora" de Bopp, no entanto, trata de assunto bastante diverso, uma vez que enfatiza apenas os sistemas verbais. Como outros contemporâneos, reivindica uma visão científica do problema (wissenschaftliche Spracheinsicht) e simpatiza-se com metáforas advindas da História Natural como "flexôes orgânicas" (organische Flexionen). A oposição estoica entre forma (Form) e significado (Bedeutung) também aparece em suas afirmaçóes, além de uma revisão das tradicionais classes de palavras, motivada pela Gramática Comparativa.

A origem comum das línguas (gemeinschaftlicher Ursprung), em seu texto, já parece consabida - provavelmente por causa das declarações de William Jones - pois as línguas sobre as quais se debruça (sânscrito, grego, persa, germânico, latim) formariam seus tempos por meio do verbum abstractum, que se mescla ao radical dos verbos. A língua original, porém, não tem nome na primeira obra de Bopp, pois a ela se refere como a "mãe comum" (gemeinschaftliche Mutter), mas sua reconstrução apresenta-nos algumas características visivelmente aglutinantes.

A influência de Grimm sobre as posteriores obras de Bopp se encontra, por exemplo, na ideia de que a língua primitiva possuía apenas três vogais $(a, i, u)$ e na de que os nomes provêm dos verbos. Tais posturas perdurarão, aliás, até final do século XIX. Além disso, as raízes dessa suposta língua-mãe compunham-se, para Bopp, de três letras e duas sílabas, postura que o aproxima do dogmatismo de Gébelin. Bopp distancia-se aos poucos da tipologia linguística de August Wilhelm von Schlegel (1767-1845), feita em 1820, e, posteriormente, da obra de Grimm (1827), aproximando-se das ideias de Wilhelm von Humboldt (17671835), com quem se correspondia. Isso é visível na explicação do "vocalismo" da conjugação verbal das línguas, isto é, na alternância vocálica do radical.

Bopp náo segue os rigorosos critérios de Rask, de modo que se pauta muitas vezes em transformaçóes que requerem semelhanças mais vagas. Além disso, inicialmente seu campo de atuação era menor: o lituano só aparecerá em suas obras em 1833 e o eslavo, em 1835. Aponta semelhanças também no grupo céltico desde 1823, mas somente consegue incluí-lo em 1839, valendo-se de engenhosas explicaçóes fônicas e influenciado pela obra de Adolphe Pictet (1799-1875), publicada dois anos antes. Bopp também fez investigaçóes incluindo o antigo prussiano (1853), o albanês (1854) e o armênio (1857) e, menos acertadamente, o malaio (1840) e as línguas do Cáucaso (1846). 


\subsubsection{Grimm}

A importância da colossal obra de Linguística Comparativa de Jakob Ludwig Karl Grimm (1785-1863) reside, acima de tudo, na valorização dos dialetos e no rompimento com a Filologia Clássica. Tal postura romântica pretende privilegiar a fala natural e encontra eco em outros autores que o influenciaram, como o jurista Friedrich Carl von Savigny (1779-1861), o qual defendia que as instituiçóes legais provinham de desenvolvimentos graduais da tradição popular. Também influenciou o seu pensamento Ludwig Tieck (1773-1853), que difundiu a poesia popular e o antigo alemão. Outros autores que podem ter contribuído indiretamente com sua obra foram August Bernhardi (1769-1820) e Johann Gottlieb Radlof (17751824). Grimm advoga ainda a favor de uma psicologia popular.

O primeiro volume da sua Deutsche Grammatik (1819-1834) saiu quando tinha 24 anos. O nome de Rask é mencionado no seu prefácio (p. XIX). Logo após publicá-lo, toma contato com novas obras de Rask. Por causa disso, reformula-o completamente. Nessa segunda edição do primeiro volume (1822) aparecerão as famosas transformaçóes fonéticas (p. 583-592), inspiradas em Rask, as quais seriam chamadas de leis dez anos depois, por John Mitchell Kemble (1832 "this law"), Rudolf von Raumer (1837 "das durch Jakob Grimm gefundende Gesetz der Lautverschiebung”), William Balfour Winning (1838:36-39 "Grimm's Law") e por Robert Gordon Latham (1841 "currently called Grimm's law"), diferentemente do que se divulga em muitos manuais, que atribuem o termo a Max Müller (1823-1900). As correlaçóes, como vimos, aparecem em Rask e, muito antes dele, em Nebrija. Costuma ainda citar-se Jacob Hornemann Bredsdorff (1790-1841) como precursor das leis de Grimm e, em certa medida, também Georg Friedrich Benecke (1762-1844).

Entender as regras propostas por Grimm como leis e o caráter dedutivo que lhe foi atribuído, contudo, parece contradizer o próprio Grimm, que se mostra textualmente avesso a conceitos lógicos nas gramáticas (allgemeinen logischen begriffen bin ich in der grammatik feind, 1822: vi). Afirma que se, por um lado, conduzem a um rigor aparente (scheinbare strenge) e uma coesáo das determinações (geschlossenheit der bestimmungen), por outro, obstruem a observação (hemmen ... die beobachtung), ou seja, a alma da pesquisa linguística (seele der sprachforschung). Essa defesa da indução, que supóe necessária da parte dos linguistas (sprachforscher), se mostra mais clara na seguinte afirmação: "quem não se atém às observaçóes empíricas (wahrnehmungen), as quais mancham toda teoria, com sua efetiva certeza, logo de início, nunca se aproximará do inescrutável espírito da língua (unergründliches sprachgeist)" (1822, p. vi). Grimm é, por isso, consciente de que suas regras não têm validade absoluta (p. 590), pois, apesar de 
explicarem grande número de fatos (erfolgt in der masse), falham nos detalhes (thut sich aber im einzelnen niemals rein $a b$ ).

As transformações que Grimm propóe seriam "deslocamentos de sons" (Lautverschiebungen) e se pautariam, exclusivamente, nas consoantes. Grimm divide-as em três grupos (ou "ordens"), seguindo uma denominação que remonta aos latinos. Cada grupo teria, por sua vez, três séries (ou seja, uma consoante labial, uma dental e uma gutural). $\mathrm{O}$ grupo das tenues equivaleria ao que hoje chamaríamos consoantes oclusivas surdas $(p, t, k)$. As medic seriam as sonoras, tanto oclusivas $(b, d, g)$ quanto fricativas $(v, \partial)$. Já as aspirate equivaleriam não só às oclusivas surdas aspiradas $(p h, t h, k h)$, mas também às fricativas surdas $(f, p$, h) e às africadas $(p f, z)$. Comparando o grego, o gótico e o alto-alemão, Grimm aponta para um movimento "descendente" (eine stufe abwärts, p. 184), segundo a visão romântica de uma progressiva decadência das línguas, ao apartarem-se da língua primitiva. Do grego, que representa os sons originais, parte para o gótico, que representa o germânico (erste Lautverschiebung) e do gótico, para o antigo alto-alemão (zweite Lautverschiebung).

Apontou-se já nesse modelo uma série de inconsistências. Jespersen (1922) vê o conjunto das aspirate como algo muito forçado, uma vez que engloba várias classes de consoantes e não uma só. Além disso, é possível encontrar erros na sua formulação: não há media, mas aspirate, para o antigo alto-alemão correspondente ao gr $p$ e ao gót $f$, por exemplo, gr poûs @ gót fotus $\cong$ aaa fuss "pé" (esperaríamos uma palavra com $\star b$ e não com $f$-no alemão). O mesmo ocorre para os correspondentes do gr $k$ e do gót $h$ (cf. gr kardía $\cong$ gót hairto $\cong$ aaa herz "coração", com $h$ - e não com $\star g$ ). Não é difícil observar que Grimm estava ainda muito preso às letras, entendidas como sinais gráficos, chegando a afirmar que a palavra schrift "escrita" tinha oito sons, computando-se o trígrafo sch [S] como três sons em vez de um só e o $f$ como dois, pois equivale a $p h$ (isto é, uma aspirata). Tais confusóes entre a figura da letra e a voz da letra, contudo, são impensáveis num autor do Renascimento, como Fernáo de Oliveira, ou mesmo para os seus contemporâneos, como Karl Moriz Rapp (1803-1883).

Seria errôneo, ainda, imaginar que Grimm aplique rigorosamente as suas "leis" às suas próprias etimologias, numa tentativa de demonstrá-las. Contudo, os autores posteriores, motivados pelo uso do termo lei, passariam a ver nas regras de Grimm algo distinto das comparaçóes de Rask, dada a dimensão dedutiva que lhes foi conferida. É verdade, porém, que Grimm, apesar de ter menos rigor, superou Rask quantitativamente em seus exemplos, de tal modo que seu empenho chegou a obscurecer a figura do linguista dinamarquês, na segunda metade do século XIX. Também a terminologia de Grimm influenciará todos os autores subsequentes: o termo alem umlaut, decalcado do din omlyd, de Rask, será 
novamente decalcado em francês por Bréal como métaphonie (port metafonia) na sua tradução francesa de Bopp de 1866-1874; o alem ablaut, igualmente, torna-se o fr apophonie (port apofonia). Na edição de 1822, muito mais dedicada a questóes fonéticas, acresceu ainda: alem anlaut, o chamado "início da palavra"; alem inlaut, o "interior da palavra" e alem auslaut, o "final da palavra". A cada uma dessas três, os linguistas do século XIX associarão as figuras retóricas da Antiguidade, chamadas "metaplasmos" nas descriçóes dos vocalismos e consonantismos.

Os três grupos de Grimm seriam mais tarde substituídos por quatro (por exemplo, $p, p h, b, b h$ ), por outros autores, no final do século XIX (Brugmann \& Delbrück, 1897, p. 92). Admitiu-se também que a língua indo-europeia deveria partir, por exemplo, de $b h$, como no sânscrito e não de $p h$, como no grego. As transformações de Grimm passaram a ser entendidas como "atos de deslocamento” (Verschiebungsakte) de todo um sistema de sons (Russer 1930, pp. 119-122).

Já em 1827, um ano após o lançamento do segundo volume da sua gramática, Bopp questionará algumas das posturas de Grimm - bem como de Eberhard Gottlieb Graff (1780-1841) - a respeito do vocalismo. Inicia-se, assim, um frutífero trabalho comparativo que caracterizará todo o século XIX. O segundo e o terceiro volume (1831) da Deutsche Grammatik serão voltados à Morfologia (assim como era o antigo volume de 1819). O quarto (1837) será dedicado à Sintaxe. Em 1840, Grimm, lança a terceira edição do primeiro volume, em que o capítulo sobre as "letras", aparece substituído pelo termo "sons".

Há possivelmente uma influência de outros autores em Grimm ainda não suficientemente estudada, como o já citado Gébelin. No seu raciocínio, Grimm, se volta às vezes ao Misticismo. Também a tese do monossilabismo da língua original (em oposição à raiz trilítere das línguas semíticas) se encontra em ambos. No seu ensaio de 1851, Grimm diz que a língua original era do tipo aglutinante com três vogais $\left({ }^{*} a,{ }^{*} i,{ }^{*} u\right)$ e poucas consoantes, não dispunha de abstraçóes e não tinha indícios de tempo, pessoas, números e modos. Grimm imagina que dos verbos viriam os nomes, como Herder. Fala-se também sobre uma associação sinestésica entre cores e vogais, muito antes do poeta simbolista Arthur Rimbaud (1854-1891) em Une saison en enfer (1873, Délires II - Alchimie du verbe). Percebe-se em Grimm uma procura de elementos eternos e invariáveis (unstillstehend) nas línguas, como nas próprias mudanças sonoras acima descritas, o que o aproxima de uma postura dedutiva e justificaria que acreditasse serem as transformaçóes motivadas pelo "espírito da língua" (sprachgeist). Outro aspecto místico é a sua obsessão por trindades (são três classes de consoantes, três vogais básicas, três declinaçóes, três gêneros, três números, três pessoas, três vozes, três tempos). Nas transformaçóes, o terceiro momento também equivaleria ao estágio perfeito. 


\subsubsection{Schleicher e os neogramáticos}

Associar a Linguística à História Natural era bastante comum no século XIX: Goethe, Rask, Rapp e Bopp diziam que as línguas eram objetos com leis fixas equivalentes, de algum modo, às dos corpos naturais orgânicos. Era uma época em que a História Natural, a Anatomia, a Fisiologia e a Química formavam paradigmas epistemológicos importantes. Entrevê-se na obra de Rask uma influência das Ciências Naturais em algumas metáforas (por exemplo, Tungemaals Natur "a natureza da língua"); Bopp afirma que as línguas são corpos naturais (Naturkörper) que se formam (sich bilden) por meio de leis definidas (bestimmte Gesetzen) e possuem um princípio vital intrínseco (inneres Lebensprincip), o qual as faz morrer (absterben) aos poucos. Essas metáforas são, contudo, esporádicas (1827b, p. 251, 1836, p. 1).

August Schleicher (1821-1868) talvez seja o que levou a metáfora naturalista à sua forma mais radical. Influenciado pela filosofia de George Wilhelm Friedrich Hegel (1770-1831) e contemporâneo de Charles Darwin (1809-1882), privilegiou o trabalho empírico das línguas, vistas em toda a sua concretude, em detrimento da pesquisa da atividade mental, dando à língua uma visão materialista que caracterizará algumas linhas da Linguística da segunda metade do século XIX. Usando da Dialética, deu ensejo a inúmeras questóes, as quais seriam desenvolvidas posteriormente. Schleicher buscou romper uma série de pressupostos da Linguística de sua época e sua atitude influenciou tanto quanto suas ideias. Entre suas ousadias há a célebre fábula escrita em indo-europeu (Kuhn \& Schleicher, 1868, pp. 206-208). Nesse período, os elementos fonéticos reconstruídos para o indo-europeu diferem muito dos das propostas subsequentes (sobretudo no vocalismo, que, para Schleicher, se compunha apenas de ${ }^{*} a,{ }^{*} i,{ }^{*} u$, como em Bopp e Grimm) e ainda mais da atual (que preveem as laringais de Saussure 1879), de modo que essa fábula foi reescrita posteriormente por vários autores.

Influenciado pelos trabalhos de Ernst Heinrich Philipp August Haeckel (1834-1919), Schleicher, antes da obra de Darwin, de 1859, já esboçava as línguas em árvores genealógicas (1853), também ilustradas na sua Deutsche Sprache, de 1860 (18743). Vê-se a influência darwiniana de forma mais evidente no título Die Darwinsche Theorie und die Sprachwissenschaft (1863). Deve-se a Schleicher o rigor de marcar as formas hipotéticas com asteriscos, prática que se segue até hoje, mas ainda náo era totalmente difundida ainda na década de 70 do século XIX. Seu Compendium de 1861-1862 influenciará toda uma série de linguistas, que deram grande ênfase à regularidade das leis fonéticas. Entre os seguidores de suas ideias encontra-se o ex-aluno de Bopp e grande divulgador da gramática histórico-comparativa, Friedrich Max Müller (1823-1900). 
Entre 1870-1878, na esteira de Schleicher, muitas regras fonéticas semelhantes à esboçada por Grimm foram descobertas. Entre elas, a célebre lei de Verner de 1875, que tornava regulares mudanças até então vistas como arbitrárias ou excepcionais. O nome dessa nova lei é uma homenagem a seu descobridor, o dinamarquês Karl Adolph Verner (1846-1896). Resolveram-se, desse modo, inconsistências teóricas por meio da reconstruçáo do acento tônico indo-europeu. Com soluçôes elegantes desse tipo, a fé nas regras fonéticas aumentou de tal forma que, ainda hoje, as regras fonéticas constituem um porto seguro para testar-se a veracidade de étimos propostos.

Soluçôes como a de Verner rapidamente se multiplicaram: assim, reconheceu-se, além da lei de Grimm, também a lei de Graßmann (1863), anterior à de Verner, que previa a dissimilação em reduplicaçôes indo-europeias. Importa dizer que Hermann Graßmann (1809-1877) era matemático, além de linguista. Não foi pequeno o entusiasmo entre os linguistas ao verem aproximar-se de ciências consagradas. No clima positivista vigente, falava-se de uma infalibilidade das leis fonéticas (Ausnahmslosigkeit der Lautgesetze). Nasce, assim, a chamada escola neogramática (junggramatische Richtung), que apresenta as leis como "sem exceçôes" (ausnahmslos). Essas leis seriam cegas à consciência dos falantes, como a evolução o é para os seres vivos. As exceçóes, toleradas por Grimm, passam a ser indesejáveis, segundo a nova visão. Desse modo, toda exceção era explicável apenas pela atuação da analogia. O indivíduo somente alteraria os resultados das leis fonéticas, por meio desse mecanismo psíquico, de forma quase involuntária. $\mathrm{O}$ método então exsurgente, em que participam leis fonéticas e o ultimum refugium da analogia, criou uma notável síntese entre a clássica oposição da língua vista como algo natural (phýsei) e como instituição humana (thései). A importância da analogia já se via em 1860 num discípulo de Humboldt, Heymann Steinthal (1823-1899), na sua obra Assimilation und Attraktion psychologisch beleuchtet. O conceito de analogia parte da Psicologia rumo à Linguística por Wilhelm Scherer (1841-1886), em 1868, e August Leskien (1840-1916), em 1876. Os grandes defensores da ausência de exceções das leis fonéticas eram dois seguidores de Schleicher, a saber, Karl Brugmann (1849-1919) e Hermann Osthoff (1847-1909), em suas Morphologische Untersuchungen (1878). No entanto, havia estudiosos que não concordavam com o afastamento da esfera cultural dos estudos linguísticos.

Em 1885, o filólogo Georg Curtius (1820-1885) critica as por ele chamadas "impropriedades" na obra de Berthold Delbrück (1842-1922), outro seguidor de Schleicher. Inicia-se uma produtiva polêmica acerca do termo lei, referente às transformaçóes fonéticas. Para Curtius, há situaçóes (como na haplologia, no redobro e nos hipocorísticos) em que nem leis fonéticas, nem analogia atuariam. Descrente de leis universais, Curtius imagina que cada fenômeno lexical deva ser 
estudado historicamente, como se faz com cada fenômeno fonológico. À polêmica, que durou de 1885 a 1887, juntaram-se muitos nomes e dessa discussão, complexificada pelos dados da recém-criada Dialetologia, nascerá uma metodologia mais madura, que culminará na própria Linguística Moderna.

Os estudos de indo-europeu continuaram pelo século XX adentro, com número menor de especialistas, mas eram bastante presentes até a Segunda Guerra Mundial. As reflexôes nascidas dos estudos histórico-comparativos cedo se transformaram em questôes de ordem teórica. No século XIX, Hermann Otto Theodor Paul (1846-1921) é, após Humboldt e Schleicher, talvez um dos mais antigos representantes da Linguística Geral. Sua obra Prinzipien der Sprachgeschichte $(18801,19205)$ coloca a sociedade acima do falante em questóes de língua. Muitas iniciativas com incursóes na Psicologia também se vislumbram nas obras de Arsène Darmesteter (1846-1888), Mikołaj Habdank Kruszewski, (1851-1887) Jan Niecław Ignacy Baudouin de Courtenay (1845-1929), entre outros.

Nesse ambiente surgem nomes de linguistas amadurecidos pela polêmica, alguns diretamente ligados aos neogramáticos, como Ferdinand Mongin de Saussure (1857-1913), que se tornou famoso pela publicação póstuma de seu curso (1916), reconstruído por seus alunos Charles Bally (1865-1947) e Albert Sechehaye (1887-1964), com base em anotaçóes. As ideias de Saussure foram exploradas pelo Círculo de Praga (1928-1939), mas somente foi incensado como "pai da Linguística Moderna” após a Segunda Guerra Mundial. Já em 1943 Louis Trolle Hjelmslev (1899-1965) afirma que Saussure é o "o único teórico que merece ser citado" por ser um "pioneiro indiscutível”. No entanto, é preciso lembrar que já em 1869, Theodor Benfey (1807-1881) havia escrito um livro sobre História da Linguística (Geschichte der Sprachwissenschaft), citando inúmeros autores, em meados do século XIX. A afirmação de Hjelmslev é obviamente exagerada, mas foi levada a sério e tomou ares dogmáticos durante mais de meio século e ainda hoje se faz sentir.

\subsubsection{Diez e a Filologia Românica}

O trabalho de Bopp e Grimm encontrou seguidores na forma de linguistas que se especializaram em alguns ramos da Indo-europeística, com o intuito de confirmar as teses recém-descobertas e aduzir mais dados para consolidá-las. Entre eles, encontram-se Johan Gaspar Zeuß (1806-1856), para as línguas célticas, e Franc Miklošič (1813-1891), para as línguas eslavas. Um dos mais importantes, contudo, foi Friedrich Christian Diez (1794-1876), que se preocupou com as línguas românicas. Sua gramática comparada escrita entre 1836-1844 e seu dicionário etimológico de 1854 se tornaram os pilares de todas as discussóes subsequentes 
que envolvessem não só a Filologia Românica, mas também a Linguística, de modo geral. Os estudos das línguas românicas sob o aspecto filológico iniciaram pelo provençal: August Wilhelm von Schlegel (1767-1845) e François-Juste-Marie Raynouard (1761-1831) são os mais citados precursores. A obra de Raynouard, publicada simultaneamente à de Bopp, em 1816, foi considerada, por uns, como superada por Diez e, por outros (entre eles, o próprio Diez), como o marco do nascimento da Filologia Românica. Classificações das línguas românicas, porém, remontam sabidamente a Dante Alighieri (1265-1321). Todavia, foi Diez quem conseguiu reunir amplos e heterogêneos aspectos linguísticos e filológicos acerca das línguas românicas literárias mais importantes: o italiano, o romeno, o espanhol, o português, o provençal e o francês, filiando-as ao latim vulgar.

Para Diez, aspectos históricos e culturais eram até mais importantes do que os linguísticos (ou glotológicos, como também se dizia), de modo que os dialetos figuravam em segundo plano. Invertendo essa perspectiva, surge a figura do indo-europeísta, romanista e filólogo Graziadio Isaia Ascoli (1829-1907), que demonstrará a possibilidade de tratar os dialetos sob a mesma ótica histórica e geográfica das línguas de cultura. Nasce a ideia da chamada tese substratista (AGI 22-23:304), atribuída ao escritor Carlo Cattaneo (1801-1869). Na polêmica com os neogramáticos, suscitada por Curtius, Ascoli imagina que se dava muita atenção à analogia. Para ele, o mesmo som ou grupo de sons poderia evoluir diferentemente de uma língua para outra. A divergência de resultados desobrigaria as exceçóes e, por conseguinte, as leis fonéticas. Muitas transformaçóes fonéticas teriam, portanto, origem individual. Ascoli é, contudo, favorável aos neogramáticos, pois vê no método deles o mesmo dos autores antigos, apesar de condenar-lhes o sensacionalismo.

Entre os seguidores de Diez - e declarado continuador de sua obra - está Bruno Paulin Gaston Paris (1839-1903), que, juntamente com Marie-Paul-Hyacinthe Meyer (1840-1917), fundara a revista Romania (desde 1872). Segue-se o Archivio Glottologico Italiano (AGI, desde 1873), fundado por Ascoli e, logo em seguida, a Zeitschrift für romanische Philologie (ZfRP, desde 1877), de Gustav Gröber (1844-1911). Antes da revista Romania, já havia outras que se dedicavam aos estudos linguísticos: o Archiv für das Studium der neueren Sprachen und Literaturen (desde 1846, fundado por Ludwig Herrig e Heinrich Viehoff), o Jahrbuch für romanische und englische Literatur (desde 1859, por Adolf Ebert e Ferdinand Wolf), o Bulletin de la Société de linguistique de Paris (desde 1869, quatro anos após a criação da Sociedade de Linguística) e a Revue des langues romanes (também desde 1869).

A partir de então, muitos outros autores colaborarão para os estudos das línguas românicas e para estudos de Linguística Geral. A imensa quantidade de 
material existente nessas revistas - fruto da recolha, ordenação e descrição de dados coletados provenientes de manuscritos e do campo - é ainda bastante inexplorada, mas formaram paulatinamente a base de cientificade para os estudos etimológicos do século XIX. Mais especificamente, entre os que se voltam para questôes etimológicas das línguas iberorromânicas, nessas revistas, estão Ramón Menéndez-Pidal (1869-1968), Friedrich Hanssen (1857-1919), Rudolf Lenz Danziger (1863-1938). Especificamente para o português citem-se Aniceto dos Reis Gonçalves Viana (1840-1914), Teófilo Braga (1845-1924), Francisco Adolfo Coelho (1847-1919), Jules Cornu (1849-1919), Carolina Wilhelma Michaëlis de Vasconcelos (1851-1925). Nesse período surgem os estudos dialetológicos. No âmbito da língua portuguesa, a figura que mais se destaca é a de José Leite de Vasconcelos Cardoso Pereira de Melo (1858-1941), fundador da Revista lusitana, desde 1887.

\subsubsection{Schuchardt}

A especialização acabou diluindo os princípios dedutivos de autores como Bopp. Voltou-se à coleta de dados, de onde nasceriam, no sentido inverso, modelos com viés fortemente indutivo. O estudo da Etimologia assume também esse aspecto e um dos mais ardorosos defensores de uma Linguística Geral com bases empiricas se concentrará na figura de Hugo Ernst Mario Schuchardt (1842-1927), professor de Graz. Já no seu livro de 1866-1868, apresenta sua original visão das línguas, bastante próxima à que seria desenvolvida em 1872 por Johann Schmidt (1843-1901), conhecida como "teoria das ondas" (Wellentheorie). Mais tarde, em sua tese defendida em 1870 (mas publicada apenas em 1900), apresenta uma crítica a Schleicher, sobretudo à sua visão de que as línguas são unidades autônomas facilmente identificáveis e de que duas línguas, uma vez apartadas, divergem entre si cada vez mais, jamais voltando a convergir-se novamente.

Como em Leibniz, a delimitação espacial de uma língua, para Schuchardt, náo é possível de ser determinada, pois não se sabe quando termina um dialeto e começa outro. Tampouco o tempo serve para definir uma língua, pois não há limites na passagem de uma forma de expressão para outra. A fragmentação linguística chega até o ponto em que é possível afirmar que cada indivíduo tem seu falar próprio, opiniấo que seria mais tarde divulgada em 1891 por Paul Passy (1859-1940).

Em suma, segundo Schuchardt, simplesmente não existem as condiçóes ideais para falarmos de leis fonéticas. Uma língua é um continuum: não é possível separá-las no espaço ou no tempo. As línguas, na verdade, seriam misturas de línguas e os dialetos, sob esse ângulo, desapareceriam completamente. Se não há leis fonéticas, tampouco há exceçôes. A preocupação de Schuchardt é epistemológica, pois pensa no estudo da linguagem como uma única ciência, com 
uma única metodologia. A conclusão de Schuchardt é que cada palavra tem uma história e seguirá como ninguém essa ideia, já presente em Grimm (jedes wort hat seine geschichte und lebt sein eigenes leben 1822, p. xiv). A essa conclusão também chegaria, mais tarde, a Dialetologia, quando afirma que um falar é uma concentração de isoglossas.

Nesse sentido, a Etimologia assumiria um papel central e a ela Schuchardt se dedicará em muitos de seus artigos. Para ele, as línguas não formariam nenhum sistema, como queriam os neogramáticos, posição assumida por toda a Linguística do século XX, após o sucesso do Cours de linguistique générale. Em suma, a língua não poderia ser vista como um organismo mecânico, como se deduz das leis fonéticas. Após a crítica de Schuchardt reviram-se algumas das posturas correntes e as leis fonéticas passam a ser entendidas apenas como meios práticos necessários para as investigaçóes etimológicas.

Ao mesmo tempo em que os neogramáticos visavam ao sistema linguístico, os dialetólogos visavam à fala (parole, nos termos do Cours de Linguistique Générale). Tal divisão era, contudo, apenas uma questão de preferências. A precisão das anotaçóes se torna cada vez mais crescente a partir da segunda metade do século XIX, com a adoção do standard alphabet de Carl Richard Lepsius (1810-1884), usado na transcrição de línguas não-europeias em periódicos de Geografia e Etnologia. Os estudos de Fonética se desenvolvem nesse período. Também alguns fatores como o convívio entre os nativos se tornou, aos poucos, indispensável. À medida que essas implementaçóes metodológicas se efetuavam, muitas das teses de Schuchardt passaram a se confirmar. Em 1877 funda-se a Revue des patois, por Léon Clédat (1851-1930); dez anos depois, surge a Revue des patois galloromains, fundada pelo abade Pierre Rousselot (1846-1924) e Jules Gilliéron (1854-1926). A ideia da confecção de atlas dialetais existia nos trabalhos de Gilliéron, que entre 1877 e 1900 trabalhará, juntamente com o vendedor de hortaliças Édmond Édmont, na coleta de informaçóes para seu Atlas linguistique de France (ALF), feito com dados obtidos em 639 lugares, com um questionário de quase duas mil palavras (6 volumes foram publicados entre 1902 e 1910). Gilliéron ressaltará, entre muitas coisas, o fenômeno da homonímia como elemento perturbador dos étimos. A informação colhida pela Dialetologia é riquíssima, o que auxiliará a Etimologia a entender significados latentes e incomuns de palavras corriqueiras. Também de grande importância são os arcaísmos conservados em variantes de menor prestígio.

Schuchardt, coerente com seus pressupostos, contrários à ideia schleicheriana de sistemas totalmente independentes, interessa-se pelas línguas pidgin e crioulas. Inicia a publicação de seus Creolische Studien (1882-1890), em que estuda os crioulos de São Tomé, Cochim, Diu, Filipinas, Melanésia, Mangalore, Ano 
Bom, Vietnã e Malásia. Os falares crioulos já haviam sido objeto de estudo de Alphonse Bos (1880) e de Adolfo Coelho (1881). As etimologias desenvolvidas por Schuchardt, sobretudo na Zeitschrift für romanische Philologie tentam enfocar vários aspectos da mesma palavra e, por isso, são longas e assemelham-se a pequenas histórias. Em todos esses trabalhos, Schuchardt enfatizava que a língua não é uma coisa, mas um fenômeno que se regula por leis sociológicas, pois diferentes estilos individuais se generalizariam mediante a imitação. A generalização, por sua vez, se deve a circunstâncias da vida exterior e a particularidades psíquicas e fisiológicas dos falantes. Por isso, nas etimologias de Schuchardt, todas as variantes regionais são avaliadas e todas as fases são percorridas. $\mathrm{O}$ mesmo conceito se busca em várias línguas e o significado sempre é mais importante do que o significante.

Destaca-se entre os atributos de Schuchardt o de ser um grande polemista, o que o aproxima, em nosso percurso historiográfico, de Sócrates e Leibniz. Em 1885, Schuchardt entra na polêmica iniciada por Curtius contra os métodos dos neogramáticos e sai vitorioso: o termo neogramático, depois dos argumentos de Schuchardt, adquirirá conotaçóes negativas nas correntes linguísticas subsequentes. Para Schuchardt, as leis da linguagem não têm aplicação geral e absoluta, como na natureza. Num tempo e num espaço definidos, uma lei fonética não tem uma mesma expansão homogênea. Mesmo num dialeto específico, há variaçóes que se atribuem a características do indivíduo falante (sexo, idade, grau de cultura, temperamento etc.). Desse modo, a expansão das leis fonéticas é diversa e acidental, onde também se devem computar fatores como: o grau de expressividade das palavras, a autoridade de onde emana e a moda. Outros fatores, como o cruzamento étnico, as mudanças de classe social e a imitação complexificam ainda mais a transmissão. Como os vocábulos possuem velocidades de mudança e frequências de uso desiguais, as transformações não são catastróficas, mas lentas. Uma palavra mais frequente sofreria modificaçóes mais profundas do que uma menos frequente. Schuchardt atingira um grau de lucidez sobre o fenômeno linguístico nunca antes demonstrado pelos teóricos.

Schuchardt foi um dos primeiros a divulgar o símbolo <, no entanto, se compararmos seu modo de usá-lo com o atual, percebe-se que o faz de maneira invertida. Dito de outra forma, para dizer " $a$ gera $b$ " em vez de escrever, como hoje se faz, $a>b$, Schuchardt escrevia $a<b$ e, para dizer " $a$ provém de $b$ " escrevia $a>b$ e não, como atualmente, $a<b$. Afirmava que, nesse símbolo, o ângulo agudo devia apontar para a origem e sua abertura, no extremo oposto, indicaria a diversidade de formas provindas de um mesmo étimo. Os étimos eram indicados por seus contemporâneos de muitas formas, algumas ambíguas, como $a$ $=b$, embora houvesse algumas variaçóes (Jules Cornu, por exemplo, costuma indicar o étimo em versalete: $\mathrm{a}=\mathrm{B}$ ). Alguns autores seguem a mesma prática de 
Schuchardt, como Adolphe Dietrich (1891). No entanto, na mesma revista em que se encontram os artigos de Dietrich, outros autores usavam o símbolo como atualmente se faz, ou seja, com o ângulo agudo apontado para o resultado da transformação e não para o étimo. No ano seguinte, para solucionar o problema gerado pelo uso ambíguo desse símbolo, Gaston Paris fez uma investigação, na qual argumentava que Schuchardt estava errado (Romania 1892, pp. 471-472). Atribui a invenção do símbolo ao americano Francis Andrew March (1825-1911) e informa que em 1870, já era adotado pelos dinamarqueses, como Karl Verner (1846-1896) e Kristoffer Nyrop (1858-1931). Vencido, mas não convencido, Schuchardt passa a usar outro símbolo, modificando levemente o formato, mas mantendo a sua suposta motivação: em vez de sua interpretação $a<b$ passou a usar $a\{b$ e, em vez de seu $a>b$, os artigos de Schuchardt passaram a adotar a notação $a\} b$. Desse modo, o símbolo continuaria a serviço de suas ideias, representando o movimento da unidade para a diversidade. A despeito dessa desagradável polêmica, a consolidaçáo do uso dos símbolos de March foi um grande passo para a formalização dos estudos etimológicos. Outro símbolo, o asterisco, para formas hipotéticas, criado por Schleicher, no entanto, aparece bem mais cedo nas revistas, sobretudo no Archivo de Ascoli. Por exemplo, Louis Havet (Romania 1877, pp. 254-257), em vez de fr ant midie < *medium < lat medícum, usa a notação mirie $=$ medi $(c)$ um. Outras sequências ainda eram marcadas simplesmente por vírgulas e não pelo sinal $>$, como em: ${ }^{*}$ midie, ${ }^{*}$ miסie, mirie, mire em vez de ${ }^{*}$ midie $>$ *miסie $>$ mirie $>$ mire.

Schuchardt, mais tarde, atacará o monogenismo de Alfredo Trombetti. Nessa altura, também se interessará pelo fenômeno de aquisição da linguagem. Sua forte personalidade e seu interesse pelas línguas artificiais entáo exsurgentes (como o volapük e o esperanto) talvez tenham sido os motivos do esquecimento de suas ideias, embora tivesse sido altamente respeitado pelos seus contemporâneos. Semelhante destino foi trilhado também por precursores do Estruturalismo que se interessaram pelas línguas artificiais, como Otto Jespersen (18601943) e Edward Sapir (1884-1939). Reler esses autores, esquecidos pelas correntes da segunda metade do século XX ainda hoje nos confere grandes surpresas, pois muitas ideias que se supóem nascidas no Estruturalismo (ou depois dele) já se encontram, por vezes, totalmente desenvolvidas em suas obras.

\subsubsection{A Etimologia da primeira metade do século XX}

Wilhelm Meyer-Lübke (1861-1936), juntamente com Diez, é um dos maiores nomes da Filologia Românica. Avesso às polêmicas teóricas de sua época, das quais soube filtrar o que havia de melhor, compôs extensas obras, entre as quais 
se destaca a sua gramática das línguas românicas (1890-1902) e seu dicionário etimológico (sigla REW, 1911-1920), sínteses quase esquemáticas dos resultados de todos os especialistas de então. Tais obras, diferentemente das de Diez, levam em consideração não só as línguas literárias, mas também todos os dialetos românicos falados.

Juntamente com Rudolf Meringer (1859-1931), Meyer-Lübke funda em 1909, a revista Wörter und Sachen, na qual estudos etimológicos se mesclam à história das palavras. Essa revista declarava perigosa e vazia de sentido a Etimologia que tomasse por base apenas a língua. Nessa perspectiva, o objeto concreto, fonte da denominação, é pesquisado juntamente com seu nome. Na divulgação do nome, levam-se em conta relaçóes do ponto de vista semasiológico e onomasiológico. Pesquisa-se sua inserção em todo o léxico da comunidade. A referência (ou como diziam, as realia) toma papel central na determinação do étimo. Segundo esse raciocínio, o aspecto exterior dos seres, seu modo de vida e seus hábitos, pois tudo isso pode influir na sua denominação. Daí o interesse por objetos domésticos, nomes de plantas e animais. O cruzamento dos dados da Etnologia com a Linguística finalmente se efetiva nessa época. Também a comparação das denominaçôes do mesmo objeto em várias línguas se torna um elemento importante no julgamento das etimologias, o que a torna mais elástica. Desse modo, fala-se de "ondas de cultura", dentro das quais está a língua. Para Meringer, a história da língua é a própria história da cultura. Tais ideias, se náo tiveram sua gênese nos escritos de Schuchardt, estavam na pauta do dia. Há várias semelhanças entre Schuchardt e Meringer: por exemplo, para ambos, as palavras não afetariam as coisas mas, inversamente, são as coisas que fundamentam as denominações. Em 1904, Schuchardt também explicita a ideia de um atlas com fotografias ou desenhos de objetos e suas denominaçóes, o que foi concretizado na Wörter und Sachen. Entre outros nomes desse movimento está Gottfried Baist (1853-1920), Max Leopold Wagner (1880-1962) e Fritz Krüger (1889-1974), autor que também trabalhou com a língua portuguesa. Tal movimento também valorizava a explicação de fundo psicológico, uma vez que a afetividade passa a ser entendida como um dos elementos que promovem a mudança linguística. Isso complexificará intensamente as futuras explicaçoóes etimológicas.

Pouco depois da fundação da revista Wörter und Sachen, Meyer-Lübke edita seu dicionário etimológico das línguas românicas, que superou o de Gustav Körting (1845-1913). Contrariamente a Schuchardt e, compatível com os neogramáticos, nesse dicionário privilegiam-se as formas e suas transformações, em detrimento do significado. Deve-se a Meyer-Lübke a aplicação do método de reconstrução de Schleicher nas línguas românicas, com o intuito de reconstruir o latim vulgar, ideia já apresentada por Gustav Gröber, em 1888. Para 
Meyer-Lübke, a situação do latim vulgar em relação ao latim escrito era comparável a uma verdadeira diglossia.

Dessa forma, a situação da Linguística e seu posicionamento frente aos fatos, no início do século XX, antes do Cours de linguistique générale, é extremamente complexo. Se, por um lado, Meyer-Lübke assume todo o resultado objetivo dos neogramáticos, por outro, as demais correntes teóricas vigentes enfocam os mais variados ângulos do mesmo fenômeno língua. Acresça-se ainda outro opositor bastante original dos neogramáticos, Karl Vossler (1872-1949), com sua linha antilogicizante valorizadora do indivíduo. Seguindo Humboldt, Schuchar$\mathrm{dt}$, Rousselot, Gauchat e, sobretudo, a obra Estetica come scienza dell'espressione e linguistica generale (1902), do filósofo Benedetto Croce (1866-1952), Vossler enfatiza a forma interna das línguas (innere Sprachform), que seria, para ele, idêntica em todos os povos (antevê-se nessa ideia a hipótese da Gramática Universal, do Gerativismo). Focaliza também a Estilística e o livre-arbítrio, com relação à aceitação ou à não-aceitação dos outros falantes. A Linguística seria, portanto, segundo Vossler, uma área da Estética e, portanto, nem uma ciência natural, nem uma sub-área da Sociologia, nem uma sub-área da Psicologia. Para ele, a ideia de leis fonéticas é tautológica e a distinção entre palavras cultas e populares apenas reflete quantidades distintas de uso. As leis fonéticas não se oporiam à analogia, uma vez que entre elas existiria apenas uma gradação. $\mathrm{Na}$ prática, tudo seria analogia: as leis fonéticas apenas refletiriam conjuntos com maiores quantidades de exemplos e uma maior dispersão no tempo e no espaço. Desse modo, pode-se dizer que Vossler se opóe tanto à corrente neogramática quanto às opiniôes do psicólogo Wilhelm Maximilian Wundt (1832-1920). Nesse cipoal de opinióes, a Dialetologia, do ponto de vista da ênfase da fala sobre o sistema, estaria a meio-caminho de Vossler e Wundt. Já o Estruturalismo, concentrando-se no sistema e nas ideias sociológicas, representado por Saussure, estaria entre os neogramáticos e Wundt.

A meio-caminho também está Leo Spitzer (1887-1960), que, na mesma época de Vossler, faz uma admirável síntese das ideias de Schuchardt, Meringer e Croce. A ele se deve a introdução da Estilística nos estudos etimológicos, uma vez que se interessa sobretudo pelos étimos obscuros e pelas criaçóes ex nihilo. É dele a ideia de que, antes de recorrer às outras línguas, é preciso esclarecer o fenômeno dentro do próprio sistema a que pertence a palavra. Tal postura fez a Linguística aproximar-se da Literatura, o que gerou polêmica com outro seguidor das teses neogramáticas, o estruturalista americano Leonard Bloomfield (18871949). Tanto Vossler quanto Spitzer podem ser considerados sucessores das ideias de Herder e de Grimm, no que toca ao interesse pela expressividade. Também diretamente ligado a essa questão expressiva está o problema do tabu linguístico, 
fenômeno que impede a livre transmissão dos étimos ao longo do tempo. $\mathrm{O}$ tabu linguístico foi problematizado por autores da década de 50 do século XX: Charles Bruneau (1952), Manlio Cortellazzo (1953), John Orr (1953) e pelo brasileiro Rosário Farani Mansur Guérios (1956). A chamada etimologia popular foi bastante estudada por Vittore Pisani (1960).

\section{AS TEORIAS DAS MACROFAMÍLIAS E A RELATIVIZAÇÃO DO MÉTODO ETIMOLÓGICO}

O schleicherianismo acabou por desenvolver, paralelamente aos estudos de ordem filológica, outras linhas nascidas sobretudo fora da Alemanha, as quais trabalharam de maneira mais radical apenas com a matéria linguística, deixando de lado todos os demais aspectos culturais. Essa postura de focar a língua per se desenvolveu duas linhas completamente distintas.

A primeira será chamada de Linguística Moderna, a qual, aos poucos, se afastou do estudo histórico, sobretudo na vertente estruturalista americana. Tal postura de negação da história estava ainda patente nos primórdios do Gerativismo. Ainda hoje, o resultado dessa atitude está bem presente, pois muito do que foi estudado no final do século XIX e início do XX foi esquecido e associado a algo "precientífico" ou "acientífico". Um ressurgimento da preocupação com dados históricos se fez sentir timidamente na década de 80, do século XX, sobretudo, por meio da Sociolinguística e, posteriormente, da Linguística Cognitiva.

No extremo oposto, os neoschleicherianos radicalizaram o método diacrônico, de modo que alguns se empenharam em construir macrofamílias ainda mais antigas do que as até então conhecidas. É o caso de Holger Pedersen (18671953), que reunia o indo-europeu, o semítico, o urálico, o esquimó-aleuta, o samoiedo, o yukaghir e o finougriano na superfamília chamada de nostrático (1903). Antes ainda, Franz Wüllner (1798-1842) reunia o indo-europeu, o semítico e o tibetano (1838). Em 1915, Edward Sapir (1884-1939) também havia mostrado semelhanças entre algumas línguas ameríndias (tronco na-dene, incluindo o haida) e as línguas sinotibetanas. Bem antes, Rask já pensara na união do urálico com o esquimó-aleuta.

Muito maior é a ousadia dos que propóem o monogenismo. Como se sabe, trata-se de uma visão bastante antiga, fundamentada na passagem bíblica da Torre de Babel (Gênesis 11:1-9), mas descartada pela Linguística do século XIX. No entanto, renasceram defensores dessa hipótese, valendo-se de métodos muito parecidos com o das reconstruçóes. Quem o fez de maneira mais consistente, no início do século XX, foi o italiano Adolfo Trombetti (1866-1929). Trombetti, contudo, defende sua tese do monogenismo por meio de uma quantidade enorme 
de línguas e de dados. Estipula que entre 30.000 e 50.000 anos atrás é possível falar de monogenismo. Trombetti é extremamente prolífico em suas obras, que levam em consideração semelhanças fonéticas e semânticas.

Além de Trombetti, o método histórico-comparativo "tradicional" foi criticado como inviável em 1957 por Joseph Harold Greenberg (1915-2001), o qual argumenta que são possíveis 4140 formas de classificar oito línguas quaisquer e que para 25 línguas o número de classificações subiria para 4 quinquilhôes. Isso é problemático, diz Greenberg, sobretudo para as línguas ágrafas: só o grupo níger-congo tem cerca de 1500 línguas, o que impossibilitaria a comparação. Portanto, Greenberg advoga que é preciso reduzir o material a ser comparado (vocabulário, morfologia e mudanças fonéticas) ao mesmo tempo em que se faz necessário aumentar o número de línguas. Esse seria o primeiro passo para uma comparação, a qual aplica em seus artigos para as línguas africanas desde 1949 até as últimas versóes na década de 80 do século XX. Segundo Greenberg, todas as línguas da África se reuniriam nas macrofamílias afroasiática (=camitossemítica), nilossaariana, níger-congo e khoisan. Greenberg finaliza seu modelo para a África em 1963 e faz o mesmo em 1971 para as línguas da Nova Guiné: sua macrofamília indopacifica inclui o grupo papua, o andamanês e as línguas da Tasmânia. Volta-se em 1987 para as da América, as quais reúne em apenas três grupos, propondo a polêmica macrofamília ameríndio, que inclui mais de 2000 línguas, com exceção do esquimó-aleuta e do grupo na-dene. Greenberg, em 2000, propóe o eurasiático (já por ele esboçado desde os anos 60 do século XX), uma fusáo do indo-europeu, do ural-altaico, do etrusco, do japonês, do coreano, do ainu, do chukchi-kamchatkano, do esquimó-aleuta e do gilyak (ou nivkh).

Quase ao mesmo tempo, na Rússia, em 1964, Vladislav Illič-Svityč (19341966) e Aron Dolgopolsky (1930-), aplicando rigorosamente o método histórico-comparativo, reúnem o grupo indo-europeu, o afroasiático, o kartveliano, o urálico, o altaico e o dravídico, retomando a antiga hipótese de Holger sobre o nostrático. Suas ideias foram divulgadas por Vladimir Antoniovič Dybo (1931-) e Vitaly Victorovich Shevoroshkin (1932-). Mais tarde, em 1988, Shevoroshkin e Mark Kaiser propuseram que o nilo-saariano e o níger-cordofaniano também deveriam integrar a mesma macrofamília. Nasce, assim, a Paleolinguística. A lista de Dolgopolsky, baseada em 250 línguas, sustenta a comparação por meio de quinze palavras mais estáveis ('eu', 'tu', 'dois', 'que/quem', 'língua', 'nome', 'olho', 'coração', 'dente', 'dedo', 'piolho', 'água', 'morto', 'lágrima' e o advérbio de negaçáo), com graus maiores ou menores de conservação.

Algumas macrofamílias são ainda mais controversas, pois reúnem grupos isolados. Em 1984, Sergei Anatolyevich Starostin (1953-2005) cria o grupo sinocaucasiano que inclui, de forma descontínua, as línguas do norte do Cáucaso, o 
sinotibetano e o ienisseiano. Em 1991, Sergei L. Nikolayev adicionaria também o na-dene ao mesmo grupo, que passa a ser conhecido como dene-caucasiano. Em 1996-1997, John D. Bengston inclui o basco, o burushaski, o sumério. Shevoroshkin, em 1998, sugere que o grupo indígena algonquino-wakashano (proposto por Sapir em 1929) também pertença ao dene-caucasiano.

Seguindo Wilhelm Schmidt (1868-1964), que propunha em 1906 a superfamília áustrica, na qual se fundem o austronésio (=malaio-polinésio) e as línguas austroasiáticas (munda, khasi-khmúico, mon-khmer), Paul K. Benedict, em 1942, apresenta o austrotai, juntando-se a essa família também o kradai e o hmong-mien (=miao-iao). Em 1989, Ilja Pejros integra esse grupo com o nostrático e o dene-caucasiano. No mesmo ano, Shevoroshkin levanta semelhanças entre o nostrático, o dene-caucasiano, o ameríndio, o australiano e o indopacífico. Por fim, desde a década de 90, John D. Bengston e Meritt Ruhlen (1944-) empenham-se para encontrar raízes em todas as línguas do mundo (o chamado protossapiens, proto-humano ou protomundo), supostamente demonstrando em 27 palavras, como, por exemplo, a famosa forma *TIK para "dedo". Citem-se ainda, neste empenho, autores como Giovanni Semerano (1911-2005), Tamaz V. Gramkelidze (1929-), Allan R. Bomhard (1943-) e Václav Blažek (1959-).

$\mathrm{O}$ que tem caracterizado a defesa desses pressupostos é o uso de instrumental teórico interdisciplinar, Morris Swadesh (1909-1967) acrescentou, em 1955, no seu método, chamado Glotocronologia, o cálculo matemático aos métodos diacrônicos e à reconstrução, da mesma forma que hoje se usa em sistemática filogenética, para o estabelecimento de cladogramas. Muito se criticou a respeito desse método, que tem retomado sua credibilidade bem recentemente. Para atingir seus fins, linguistas também têm buscado corroboração de seus resultados em dados arqueológicos, entre os quais, os trabalhos de Marija Gimbutas (19211994), Andrew Colin Renfrew (1937-), Christy G. Turner e outros. Também os geneticistas têm sido muito citados, entre eles Stephen L. Zegura, Laurent Excoffier, Alberto Piazza, Guido Barbujani (1955-), Robert Reuben Sokal e, principalmente, Luigi Luca Cavalli-Sforza (1922-). Deslocamentos humanos, comprováveis pelo estudo do DNA, em épocas anteriores ao desenvolvimento da escrita, têm sido associados a protolínguas, dando apoio aos estudos diacrônicos. Suas opinióes também têm sido bem-recebidas por alguns e ferozmente criticadas por outros. Para Cavalli-Sforza, por exemplo, o dene-caucasiano, o ameríndio e o nostrático se juntariam no eurasiano, excluindo três das superfamílias africanas, o australiano e o indopacífico.

É preciso, contudo, alertar que uma crítica honesta e detalhada dos métodos empregados nessas macrofamílias ainda está por ser feita, de modo que é difícil avaliar o quanto houve de progresso real nos estudos diacrônicos, como táo 
apressadamente se alardeia. Também parece precipitado afirmar que é necessário anular importantes resultados de pesquisas mais antigas, mais comedidas, defendidas pelos que relutam em aceitar grandes agrupamentos em macrofamílias. Às sensacionais descobertas que vêm ganhando certo terreno nas discussóes linguísticas, alia-se talvez um novo furor iconoclasta, sobretudo da parte de divulgadores como Ruhlen. Com isso, corre-se o risco de se ignorarem as ideias de geraçóes inteiras de autores, como já ocorreu em meados do século XIX e, novamente, na metade do século XX. Tais posturas devem ser cuidadosamente avaliadas antes de os novos modelos se transformarem em verdades dogmáticas reacionárias e, assim, de maneira paradoxal, se tornarem óbices para futuros questionamentos válidos que façam progredir, de fato, a ciência linguística e a Etimologia, em particular.

\section{CONCLUSÓES}

Conquistas relativas ao conhecimento do fenômeno etimológico por meio do desenvolvimento de uma Etimologia de caráter científico necessitaram, como visto, do afastamento da intuição, da explicação intrassistêmica e da criatividade arbitrária nas propostas de étimos, bem como da necessidade de provas, testemunhos, critérios e analogias fundamentadas em outras palavras e línguas. $\mathrm{O}$ surgimento das chamadas leis fonéticas remonta ao século XV com Nebrija, a comparação linguística já se encontra amadurecida em autores do século XVIII, como Gyarmathi, o rigor na aplicação das regras inicia-se com Rask no início do século XIX. A isso acrescentou-se, desde Grimm, a necessidade de evitar a explicação ad hoc, por meio de vasta rede de correspondências, do instrumental simbólico de Schleicher, do rigor neogramático e da equivalência qualitativa entre línguas oficiais e dialetos, desde Schuchardt. Por fim, na virada do século XX, surge entre as variáveis o papel do indivíduo e do seu estilo nos étimos. Com a interrupção da crescente complexificação da linha de raciocínio etimológico por causa das guerras mundiais e pela negaçáo política consequente dos valores de suas conquistas, todo o raciocínio desenvolvido pela Linguística Histórico-Comparativa no século XIX se tornou esquecido. A retomada dos estudos diacrônicos só ocorre no final do século XX, por meio da Sociolinguística e do Funcionalismo. No início do século XXI, não só a necessidade de conhecer os autores clássicos, mas também a possibilidade de síntese entre esse conhecimento oitocentista com algumas conquistas das correntes da Linguística Moderna é ainda algo por ser feito. No caso particular da língua portuguesa, além da aplicação do conhecimento integrado, um estudo especializado de substratos e superstratos com vistas sobretudo a revisóes da etimologia disponível, tal como a de Corriente (2008) também está ainda por ser desenvolvido. 


\section{BIBLIOGRAFIA}

Bopp, Franz. 1816. Über das Conjugationssystem der Sanskritsprache in Vergleichung mit jenem der griechischen, lateinischen, persischen und germanischen Sprache. Frankfurt am Main: Andräische Buchhandlung. [reimpr. por Harris, Roy (org.). Foundations of indo-european comparative philology. v.1. London/ New York: Routledge, 1999].

Bopp, Franz. 1820. Analytical comparison of the Sanskrit, Greek, Latin and Teutonic languages, shewing the original identity of their grammatical structure. Annals of Oriental Literature. London. [reimpr. em koerner, Konrad (org.). Amsterdam studies in the theory and history of Linguistic science. v3. Amsterdam/ Philadelphia: John Benjamins, 19894]

Bopp, Franz. 1827a [1836²]. Vocalismus oder Sprachvergleichende Kritiken: über J. Grimm's Deutsche Grammatik und Graff's althochdeutschen Sprachschatz mit Begründung einer neuen Theorie des Ablauts. Berlin : Nikolaische Buchhandlung.

Bopp, Franz. 1827b. [Recensão a] Grimm 1822-26a. Jahrbücher für wissenschafliche Kritik. Berlin. Febr, pp. 251-6 ; Mai, pp. 725-59.

Bopp, Franz. 1833. Vergleichende Grammatik des Sanskrit, Zend, Griechischen, Lateinischen, Litauischen, Gotischen und Deutschen 6v. Berlin: Ferdinand Dümmler, v.1 $1833\left(1857^{2}, 1868^{3}\right)$, v.2 1835, v.3 $1837\left(1861^{2}\right)$, v.4 1842, v.5 1849, v.6 1852. [trad. francesa por Bréal, Michel. Grammaire comparée des langues indo-européennes. Paris : Imprimerie Impériale/ Imprimerie Nationale, 1866-1874].

Bos, Adolphe. 1880. Note sur le créole que l'on parle a l'île Maurice. Romania, 9, pp. 570-8.

Brosses, Charles de. 1765. Traité de la formation mécanique des langues et des principes physiques de l'étymologie. Paris : Saillant, Vincent \& Dessaint, v.1. [disponível em http://gallica2.bnf.fr/ark:/12148/bpt6k50476b.]

Brugmann, Karl. 1885. Zum heutigen Stand der Sprachwissenschaft. Straßburg: K. J. Trübner. [republ. em wilbur, Terence H. The Lautgesetz-controversy: a documentation. Amsterdam: John Benjamins, 1977].

Brugmann, Karl; Delbrück, Berthold. 1886. Grundriss der vergleichenden Grammatik der indogermanischen Sprachen. Straßburg: Karl J. Trübner, v.1. 1886, 1897², v.2 1888-1893; 
1906-1916², v.3 1893, v.4. 1897, v.5 1900 [trad. resumida para o francês: Abrégé de grammaire comparée des langues indo-européennes. Paris: Klincksieck, 1905].

Brugmann, Karl; Osthoff, Hermann. 1878. Morphologische Untersuchungen auf dem Gebiete der indogermanischen Sprachen. Leipzig: Hirzel.

Cavalli-Sforza, Luigi L. 1996. Geni, popoli e lingue. Milano: Adelphi. [trad. ingl. Genes, peoples and languages. New York: Penguin, 2000; trad. port.: Genes, povos e línguas. São Paulo: Companhia das Letras, 2003].

Coelho, Francisco Adolfo. 1881. Os dialetos romanicos ou neo-latinos na Africa, Asia e America. Boletim da Sociedade de Geografia de Lisboa, 2a série, 3, pp. 129-96, 1881; $3^{\text {a }}$ série, 8, pp, 451-478, 1882; 6a série, 12: pp. 705-755, 1886.

Corriente, Federico. 2008. Dictionary of Arabic and allied loanwords: Spanish, Portuguese, Catalan, Gallician and Kindred Dialects. Leiden/Boston: Brill.

Curtius, Georg. 1885. Zur Kritik der neuesten Sprachforschung. Leipzig: S. Hirzel. [republ. em wilbur, Terence H. The Lautgesetz-controversy: a documentation. Amsterdam: John Benjamins, 1977].

Delbrück, Berthold. 1885, 1893³. Die neueste Sprachforschung: Betrachtungen über Georg Curtius' Schrift “Zur Kritik der neuesten Sprachforschung”. Leipzig: Breitkopf \& Härtel. [republ. em wilbur, Terence H. The Lautgesetz-controversy: a documentation. Amsterdam: John Benjamins, 1977].

Diez, Friedrich C. 1836-1844. [1876-1877] $]^{4}$. Grammatik der romanischen Sprachen. 3v. Bonn: Eduard Weber.

Diez, Friedrich C. 1853.[18784] ${ }^{4}$. Etymologisches Wörterbuch der romanischen Sprachen. Bonn: A. Marcus.

Dutens, Ludwig. 1789. Gothofredi Guillelmi Leibnitii. Opera omnia. 6v. Genèvre: Fratres de Tournes.

Gamkrelidze, Thomas V.; Ivanov, V. 1973. Sprachtypologie und die Rekonstruktion der gemeinindogermanischen Verschlüsse: vorläufiger Bericht. Phonetica, 27, pp. 150-6. 
Gébelin, Antoine Court de. 1773-1782. Monde primitif analysé et comparé avec le monde moderne. Paris : Chez l'auteur/Valleyre/Sorin/Duran.

Gébelin, Antoine Court de. 1776. Histoire naturelle de la parole, ou précis de l'origine du langage \& de la grammaire universelle. Paris : Chez l'auteur/Boudet/Valleyre/Veuve Duchesne/Saugrain/Ruault.

Giambullari, Pier Francesco. $1546\left(1549^{2}\right)$. Il Gello: ragionamenti de la prima et antica origine della toscana et particularmente della lingua fiorentina. Florença: Per il doni.

Gilliéron, Jules; Roques, Mario. 1912. Études de géographie linguistique d'aprés l'Atlas linguistique de la France. Paris: Champion.

Greenberg, Joseph H. 1963. The languages of Africa. Bloomington: Indiana University.

Greenberg, Joseph H. 1971. The Indo-Pacific hypothesis. In: sebeok, Thomas A. (ed) Current trends in linguistics, v. 8. The Hague, pp. 807-871

Greenberg, Joseph H. 1987. Language in the Americas. Stanford: Calif.

Greenberg, Joseph H. 2000. Indo-European and its closest relatives: the Eurasiatic language family, 2v. Stanford: Stanford University Press, v.1. 2000, v.2. 2002

Grimm, Jacob. 1819. Deutsche Grammatik. Göttingen: Dieterischsche Buchhandlung, v.1 $1819^{1}, 1822^{2}, 1840^{3}$, v.2 1826, v.3 1831, v.4 1837. [republ. por London: Routledge, 1999].

Heine, Bernd; kuteva, Tania. 2002. World lexicon of grammaticalization. Cambridge: Cambridge University.

Herder, Johann Gottfried von. 1772. Abhandlung über den Ursprung der Sprache. Berlin: Christian Friedrich Voß.

Hjelmslev, Louis T. 1943. Omkring sprogteoriens grundlæggelse. København: E. Munksgaard. [trad. Prolegômenos a uma teoria da linguagem. São Paulo: Perspectiva, 2003²].

Humboldt, Wilhelm v. 1836. Über die Verschiedenheit des menschlichen Sprachbaues und ihren Einfluss auf die geistige Entwickelung des Menschengeschlechts. Berlin: Königliche Akademie der Wissenschaften. 
Jespersen, Otto. $1922\left(1954^{10}\right)$. Language: its nature, development and origin. London: George Allen \& Unwin.

Jespersen, Otto. 1887. Zur Lautgesetzfrage. (Friedrich Techmers) Internationale Zeitschrift für allgemeine Sprachwissenschaft. Leipzig, 3, pp. 188-217. [republ. em wilbur, Terence H. The Lautgesetz-controversy: a documentation. Amsterdam: John Benjamins, 1977].

Kaiser, Mark; Shevoroshkin, Vitaly. 1988. Nostratic. Annual Reviews of Anthropology. Palo Alto 17, pp. 309-29.

Kuhn, Franz Felix Adalbert; Schleicher, August (org.). 1868. Beiträge zur vergleichenden Sprachforschung auf dem Gebiete der Arischen, Celtischen und Slawischen Sprachen. v.5. Berlin: Ferdinand Dümmler/ Harrwitz \& Gossmann.

Lepsius, Carl Richard. $1863^{2}$. Standard alphabet for reducing unwritten languages and foreign graphic systems to a uniform orthography in European letters. London/Berlin: Williams \& Norgate: W. Hertz.

Locke, John. 1690. Essay concerning human understanding. London: Thomas Tegg. [trad. portuguesa: Ensaio acerca do entendimento humano. São Paulo: Abril Cultural, 1978.]

Méridier, Louis (ed). 1931/ 20037. Platon: œuvres complètes, tome V, 2e partie Cratyle. Paris: Les Belles Lettres.

Meyer-Lübke, Wilhelm. 1890-1902. Grammatik der romanischen Sprachen. 4v. Leipzig: Reisland.

Meyer-Lübke, Wilhelm. 1911-1920. Romanisches etymologisches Wörterbuch. Heidelberg: Carl Winter.

Müller, Max. 1863, 1864². On the principles of etymology. In: Lectures on the science of language. v.2. London: Longman, Roberts \& Green. [trad. portuguesa Sobre os princípios da etimologia: Palestra vi da obra A ciência da linguagem, Rio de Janeiro: Non edictandi, 2007 por Paulo Mario Beserra de Araujo]

Nebrija, Elio Antonio de. 1479. Grammatica castellana. Salamanca: Juan de Zúńiga. [Madrid: Fundación Antonio de Nebrija, 1992]. 
Nunes de Leão, Duarte. 1576. Ortographia da lingoa portuguesa: obra vtil \& necessaria assi pera bem screuer a lingoa Hespanhol como a Latina \& quaesquer outras que da Latina teem origem ; Item hum tractado dos pontos das clausulas. Lisboa: João da Barreira. [http://purl.pt/15/3/]

Nunes de Leão, Duarte. 1606. Origem da lingua portuguesa. Lisboa: Pedro de Crasbeeck. [Lisboa: Pro Domo, 19454; http://purl.pt/50/3/].

Paul, Hermann Otto Theodor. $1880\left(2002^{10}\right)$. Prinzipien der Sprachgeschichte. Halle: Max Niemeyer. [trad. Lisboa: Calouste Gulbenkian, 1983²].

Rask, Rasmus K. 1811. Vejledning til det Islandske eller gamle Nordiske Sprog. Kjöbenhavn: Schubothe. [trad. inglesa por H. Lund. A short practical and easy method of learning the Old Norsk tongue or Icelandic language. London: Franz Thimm, 1868]

Rask, Rasmus K. 1818. Undersögelse om det gamle Nordiske eller Islandske Sprogs oprindelse. Kjöbenhavn: Paa den Gyldendalske Bokhandlings Forlag. [reed. por Louis hjelmslev (org.). Ausgewählte Abhandlungen, v. I. København: Levin and Munksgaard, 1932. e por Roy harris. Foundations of indo-european comparative philology. v.1. London/ New York: Routledge, 1999; tradução para o inglês: A Grammar of the Icelandic or Old Norse Tongue. London: 1843 (Amsterdam: 1976², 1989³)]

Raynouard, François-Juste-Marie. 1816. Grammaire romane ou Grammaire de la langue des trobadours. Paris : Didot.

Raynouard, François-Juste-Marie. 1821. Grammaire comparée des langues de l'Europe latine dans leurs rapports avec la langue des troubadours. Paris :Didot.

Ruhlen, Merritt. 1987. A guide to world's languages. v.1. London/Melbourne/Auckland: Edward Arnold.

Ruhlen, Merritt. 1994a. On the origin of languages: studies in linguistic taxonomy. Stanford: Stanford University Press,

Ruhlen, Merritt. 1994b. The origin of language: tracing the evolution of Mother Tongue. New York: John Wiley \& Sons.

Russer, Wilhelmina S. 1930. De germaansche klankverschuiving: een hoofdstuk uit de geschiedenis der germaansche taalwetenschap. Haarlem: Tjeenk Willink \& Zoon. 
Sapir, Edward. 1915. The Na-dene languages : a preliminary report. American Anthropologist, 17, pp. 534-58.

Saussure, Ferdinand Mongin de. 1879. Mémoire sur le système primitif des voyelles dans les langues indo-européennes. Leipzig : Teubner.

Saussure, Ferdinand Mongin de. 1916. Cours de linguistique générale. Paris: Payot. [trad. portuguesa: Curso de linguística geral. São Paulo: Cultrix, s/d]

Schlegel, Karl Wilhelm Friedrich von. 1808. Über die Sprache und Weisheit der Indier: ein Beitrag zur Begründung der Alterthumskunde. Heidelberg: Mohr \& Zimmer.

Schleicher, August. 1860. Die deutsche Sprache. Stuttgart: J. G. Cotta.

Schleicher, August. 1861. Compendium der vergleichenden Grammatik der indogermanischen Sprachen: kurzer Abriss der indogermanischen Ursprache, des Altindischen, Altiranischen, Altgriechischen, Altitalischen, Altkeltischen, Altslawischen, Litauischen und Altdeutschen. Weimar: H. Boehlau, v.1 1861, v.2 1862. [trad. inglesa resumida: Compendium of the Comparative Grammar of the Indo-European, Sanskrit, Greek, and Latin Languages. London: Trübner and Co., 1874].

Schmidt, Johannes. 1872. Verwandtschaftsverhältnisse der indogermanischen Sprachen. Weimar: Böhlau.

Schuchardt, Hugo E. M. 1866. Der Vokalismus des Vulgärlateins. Leipzig: Teubner, v.1 1866, v.2. 1867, v.3 1868.

Schuchardt, Hugo E. M. 1855. Über die Lautgesetze - Gegen die Junggramatiker. Berlin: R. Oppenheim. [republ. em wilbur, Terence H. The Lautgesetz-controversy: a documentation. Amsterdam: John Benjamins, 1977].

Schuchardt, Hugo E. M. 1900. Über die Klassifikation der romanischen Mundarten (1870). Graz: Styria.

Silva Neto, Serafim da. 1950. Introdução ao estudo da língua portuguesa no Brasil. Rio de Janeiro: inl. [Rio de Janeiro: Presença, 19865]

Trombetti, Alfredo. 1905. L' unità d'origine del linguaggio. Bologna : Luigi Bertrami. 
Trombetti, Alfredo. 1921. Puluga : il nome più diffuso della divinità. Bologna: Stabilimenti Poligrafici Riuniti. [Extrato de Rendiconto della sessioni della R. Accademia delle Scienze dell'Istituto di Bologna - Classe di Scienze Morali - Serie seconda -5].

Trombetti, Alfredo. 1923. Elementi di glottologia. Bologna: Nicola Zanichelli.

Vasconcelos, José Leite de. 1901. Esquisse d'une dialectologie portugaise. Paris: Aillaud $\&$ Cie. [tese de doutorado, republ. em Lisboa: Instituto Nacional de Investigaçáo Científica/ Centro de Lingüística da Universidade de Lisboa, 1987].

Vasconcelos, José Leite de. 1928. Opusculos. v2. Dialectologia (parte 1). Coimbra: Imprensa da Universidade.

Vasconcelos, José Leite de. 1985. Opusculos. v6. Dialectologia (parte 2). Coimbra: Imprensa Nacional/ Casa da Moeda.

Viaro, Mário Eduardo. 2004. Por trás das palavras. São Paulo: Globo.

Viaro, Mário Eduardo. 2011. Etimologia. São Paulo: Contexto.

Wüllner, Franz. 1838. Über die Verwandtschaft des Indogermanischen, Semitischen und Tibetanischen nebst einer Einleitung über der Ursprung der Sprachen. Münster: Theissing. 